Document downloaded from:

http://hdl.handle.net/10251/169541

This paper must be cited as:

Guerola-Navarro, V.; Oltra Badenes, RF.; Gil Gómez, H.; Gil-Gómez, J. (2020). Customer relationship management (CRM): a bibliometric analysis. International Journal of Services Operations and Informatics. 10(3):242-268. https://doi.org/10.1504/IJSOI.2020.108988

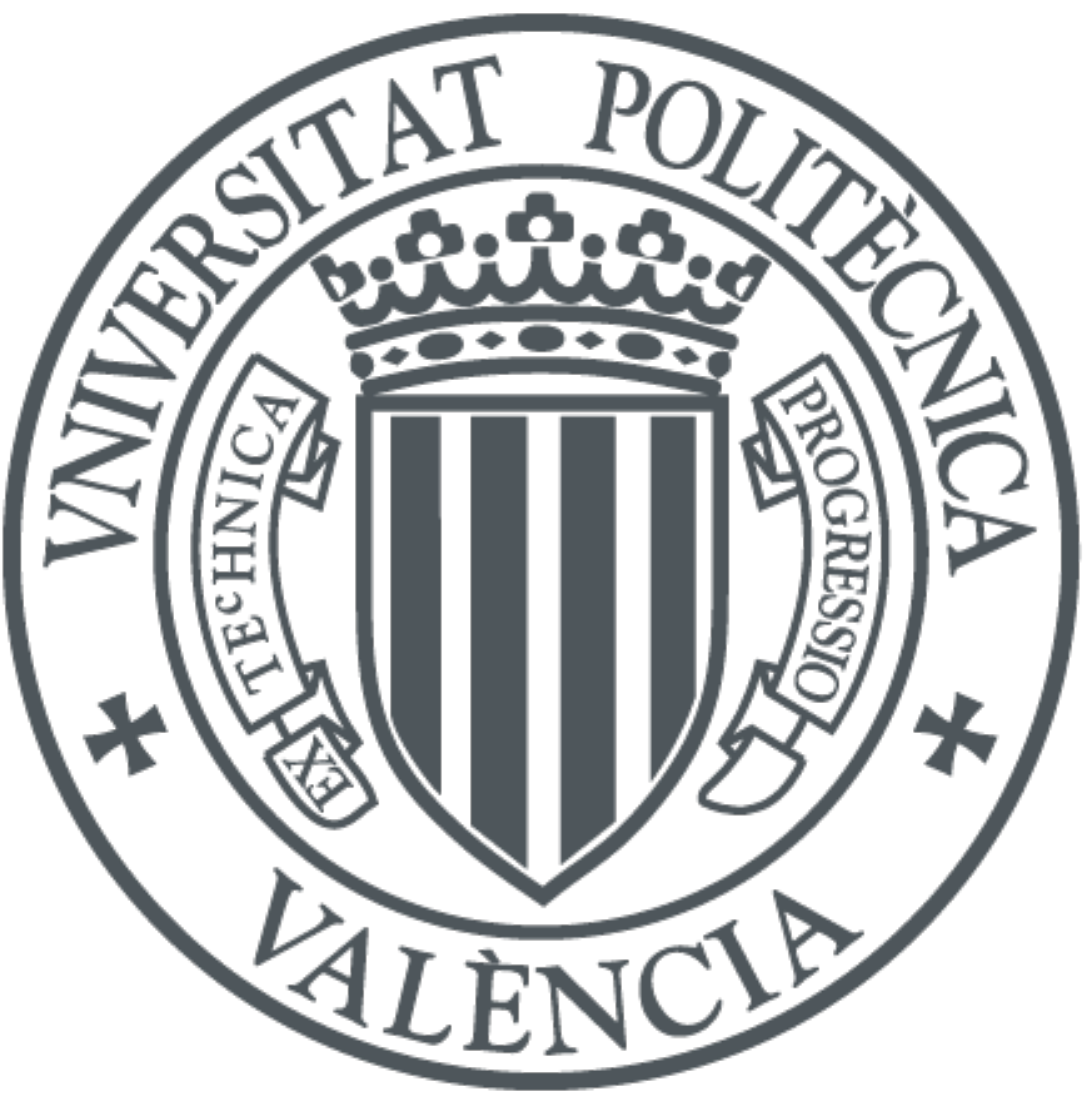

The final publication is available at

https://doi.org/10.1504/IJSOI.2020.108988

Copyright Inderscience

Additional Information 


\section{Customer Relationship Management (CRM): A Bibliometric Analysis}

\section{Keywords}

Customer Relationship Management; CRM; Business Intelligence; Marketing; Customer Service; Services; Sales Force Automation.

\section{Abstract}

This is a bibliometric study of the publications about Customer Relationship Management (CRM), as one of the nowadays most implemented and extended Enterprise Management Software. The objective of this paper is twofold: on the one hand to analyze the impact and focus of influence of the different authors and entities that have been researching on CRM, and secondly to determine (based on the results of the bibliometric study of the publications on CRM) if it may be of interest to investigate and deepen the benefits and impact on CRM results as a modern and leading enterprise management solution.

Bibliometrics is a fundamental field of information science that studies bibliographic material quantitatively. This study presents a o bibliometric overview of CRM research using the Web of Science database, identifying the most prolific and influential journals, authors, institutions and countries, considering the period since 1900 to 2017. A database with 1.685 results has been analyzed, showing as main results that Expert Systems with Applications is the most prolific Source title or journal in the field, Verhoef P.C. from Groningen University is the most citated author and Van den Poel D. from Ghent University is the most prolific author with 31 published papers. Ghent University is the most productive institution with the highest number of published papers, and University of Maryland College Park has published the most citated papers. It also shows that USA is definitely the most influential Country with the highest number of published papers (the second one is UK with nearly the third of publications) and with the highest number of citations (again, the second one is UK with the fifth part of citations that USA). Specially interesting the rank of Spain, where the investigation is taking place, with the eight rank on published papers and the twelfth rank on paper citations.

Based on the results, we can conclude that, effectively and as it was assumed, CRM is a booming and very interesting solution as a trending topic to continue researching in subsequent papers.

\section{Introduction}

This document is a workout studying the influence that Customer Relationship Management (CRM) is having among the modern business world. This technology is one of the modernist components of the Business Intelligence suite (Dumas et al., 2018), specifically focused on the customer (external) information (Negash and Gray, 2008). The main objective of this paper will therefore be to review the literature on previous bibliometric studies, and in case of not finding any modern study of a complete scope on CRM, develop a bibliometric study on CRM that allows to know the most influential sources of information and research on technology, and identify the most influential papers for further studies on the value and applicability of the benefits of using CRM in modern companies.

CRM was initially considered a key tool for managing and optimizing the sales force automation. Since the 1970s where it was firstly launched into the market (Buttle, 2004), CRM has been experienced a process of adaptation to the modern business needs, mostly in a very changing and dynamic world where changing needs makes more and more critical the use of a customizable tool. Nowadays, one of the most challenging hits for a successful enterprise is to convert the collected data into actionable information, and here CRM becomes a key technical solution as a valuable tool for identifying, extracting and transforming data into it. 
This is how enterprises demand and receive more return from their investments, especially with applications such as sales-force automation, service automation, and marketing automation.

Seeing the market value and specifications for CRM and matching them with the most valuable features for successful firms in the modern competitive market, this paper plans to state the influence and value of this CRM technology through a bibliometric study of the published papers about its content, value, benefits, and influence. This paper plans to review firstly the literature about the solution CRM, and secondly about bibliometrics (the science that will help us understand which the most valuable focus of research activity around CRM are).

After literature review, there is a description of the methodology for getting a clear picture of the volume and influence of published researches and studies. The raw tables for the publishing journals are presented in this study ranked per timely evolution, per number of citations, per prolific and influential authors, per productive and influential institutions, and finally per Country.

The conclusion has to be with the growing influence that CRM is having day after day, and with the core authors, core institutions, and core countries for CRM technology investigation efforts. The main outcome is then the global actual picture where CRM investment is being located, and the most influential papers and researchers that may help understand the market value of CRM.

These outcomes give rise to subsequent studies on CRM, to determine the impact of the use of this technology on business results and on the improvement of the supplier-customer relationship in a sustainable business management environment.

\section{Literature Review}

This paper follows the Bibliometric analysis methodology, a scientific methodology for studying and classifying bibliographic material quantitatively. Recent studies showed that bibliometrics can provide a lot of information regarding a research discipline. Nowadays it has become a very popular way to assess the state of the art of a scientific discipline, mostly with the actual easy access to scientific literature through the Internet (Allen et al., 2009). The objective of this study is to identify the most influential research and the main trends over time for the subject we are interested on, being for this a very useful tool bibliometrics as it provides a general picture of the research area in study.

\section{Customer Relationship Management (CRM)}

CRM was born in the 1970s, as a new tool for managing and optimizing the sales force automation inside the Enterprises (Buttle, 2004). CRM has arrived nowadays to be one of the most popular tools for Enterprise Information Management, not only for sales and marketing purposes by helping organizations manage customer interactions more effectively (King and Burgess, 2008) but also for knowledge management and for organizational behavior understanding. CRM was defined as a combination of processes, people and technology looking for the best understanding of a company's customers (Chen and Popovich, 2003). It is also the modern integration approach of relationship management when customer retention and relationship management is the main focus.

CRM has become a way to survive in a globalized market where enterprises need to gain competitive advantages, not only the leading-edge ones but also all the competitive targeted ones (Buttle, 2004). Customer Relationship Management is much more than a software to install, it is a real reinvention of the way we do business, the way we put the customer in the main and definite central point of all our view and efforts (Chen and Popovich, 2003; Guerola-Navarro et al., 2020). In this world were all the industrial and final customers expect to be cared and dealt as special and irreplaceable ones, the information got in the past about customers and relationships becomes critical and valuable from the beginning to the end. CRM has become a business necessity not only for High sized enterprises but also for the Small and Medium enterprises wanting to compete and survive in the twenty-first century. For these enterprises there is the clear need to become customer-centric focused and firmly decided to reach the targeted Customer Loyalty.

Customer loyalty is the most valued outcome of marketing from a relational perspective. Relationship marketing is the global marketing approach to offering more than a core product in order to satisfy the longterm value needs for the customers (Grönroos, 1997). Customer Relationship Management is a key tool for adopting a true relational marketing plan and for considering the customer is in a relational mode. Despite 
of the initial bad publicity that CRM had with high levels of failure during project implementations, Customer centric orientation makes really CRM a valued and needed technology that seems to be here to stay.

\section{Bibliometrics}

Regarding bibliometrics, there was provided a first definition focused on the use of this discipline in the 1980s, leaving the concept open for further development (Broadus, 1987). This initial concept has been modernly updated by (Bar-Ilan, 2008) from the general perspective of informetric, having said that the Internet has potentized the scope of these studies. Bibliometric studies have evolved since then, incorporating new technologies as key tools to determine the influence of authors, institutions, countries, etc. in the field of scientific and research publications. In the most recent publications, the influence of the use of powerful computer tools for data analysis is observed, especially in terms of data processing capacity when large volumes of information are available (Deng and Lin, 2012; Yin, 2013; Cadez, 2013; James et al., 2015; Zyoud and Fuchs-Hanusch, 2017; Liang and Liu, 2018). In the current bibliometric studies on Big Data and Business Intelligence, we can clearly see the importance and increasing impact that these tools are having on the ability to process data in general, and as a focus of bibliometric study in particular (Liang and Liu, 2018; Vicedo et al., 2018; Gil et al., 2010).

Looking into the most popular topics for bibliometrics studies, there is still not a huge amount of publications about CRM, but this study shows how CRM interest has been significantly growing-up during last years all over the scientific world. CRM has been identified as one of the greatest technological contributions to enterprises in the 21 st century (Chao et al., 2007). Despite of the impact of CRM in the modern management structures, there are still few studies based on bibliometrics analysis for CRM. It also studied the technology trends and forecasts of CRM from 1991 to 2005 (Chao et al., 2007). It was compared data mining and CRM trends using bibliometrics for years 1989 to 2009 by (Tsai, 2011). The present paper has the aim to extend the period of bibliometrics research until 2017, given that CRM is one of the most relevant technologies in modern era for increasing workforce productivity in the Information Age (Attaran et al., 2019).

Nevertheless, there are many sciences and research areas where Bibliometrics has been used since it was introduced in the 1980s. Seeing the influence areas of CRM as Management solution, is very interesting to evaluate how bibliometrics has been empowering the research studies about three directly related areas: Management, Economics, and Marketing. Economics has been one of the sciences where more attention has been put on by bibliometric analysis from multiple perspectives. The influence of economic journals was studied by several researchers (Autor, 2012; Card and DellaVigna, 2013; Kocher and Sutter, 2001; Laband, 2013; Laband and Piette, 1994; Stern, 2013; Sternberg and Litzenberger, 2005; Süssmuth et al., 2006), identifying the most influential journals, authors, and institutions. Marketing has been another focus area for these studies. Citation analysis was used for analyzing the influence of marketing journals (Baumgartner and Pieters, 2003), and a ranking between the publications in the major journals was stablished (Tellis et al., 1999). Some other studies have analyzed the influence of marketing scholars, institutions and countries (Chan et al., 2009; Chan et al., 2012a; Chan et al., 2012b; Stremersch and Verhoef, 2005). One of the many disciplines where bibliometrics has been used is the paper by Podsakoff et al. (2008) in Management; in this study the authors developed a method for identifying the most influential authors and institutions, through the number of publications and the citation analysis. Similar studies in management developed by other authors are available, including (Gomez-Mejia and Balkin, 1992; Kirkpatrick and Locke, 1992; Trieschmann et al., 2000).

Having said that CRM has not been one of the most popular subjects of bibliometrics study, this paper aims to place the most important centers of influence of CRM within recent scientific literature. These centers of influence, having reviewed previous bibliometric studies, should logically be considered among the authors, entities, journals, and most influential countries on this subject. The methodology used to detect these centers of influence as well as their relative importance in the world of CRM publications are detailed below. Subsequently, they present the results of the bibliometric study carried out with the data on the publications from the beginning of the years until the end of 2017.

\section{Methodology}

The final objective of this paper is to study the impact of the publications of each author, entity, country, etc. for which a methodology that reviews and measures the productivity of each of them is used, mainly and as 
previously stated, through the number of publications, number of citations, and the h-index. This methodology is explained below, as well as the results obtained.

This article analyses the information got through considering total number of papers, total citations and the h-index (Merigó et al., 2015), including authors, institutions and countries in the study. There have been several approaches on how to classify the value of research (Podsakoff et al., 2008):

- The publication count has usually been considered as the best measure for establishing the productivity of an author, institution or country (Borokhovich et al., 1995), but it has many limitations because there is no fixed way to determine how to compare and differentiate the specific nature of each paper.

- The use of the impact factor provided by WoS has been criticized, despite of having been commonly accepted traditionally as relevant indicator. Nowadays, it is becoming more relevant to use a fiveyear impact factor, due to the easiness of manipulation of the impact factor by using a self-citation policy.

- The number of citations is the most common indicator for measuring the influence of a paper, author, institution or Country, despite of having also some limitations on measuring the relevance of this indicator.

- A highly accepted index is the $h$-index (Hirsch, 2005). This index combines publications and citations under same framework. An $h$-index of 50 for a set of papers means that at least 50 papers have received 50 citations or more. The combination of publications and citations seems to be really valuable information, but it has still some limitations.

The database that is going to be used is Web of Science (WoS), owned by Thomson \& Reuters. WoS covers most of the known scientific disciplines with more than 50.000 .000 papers in more than 15.000 journals. We assume that WoS refers only high-quality journals, with on time publication and review of papers, scientific criteria for reviewing process and a wide dissemination through the Internet and most used channels for scientific papers publication. Regarding authorship and institutions, one unit has been given to each author or institution that have contributed to the paper. Talking about authorship, this paper tries to identify the influence and productivity for each of them, being the publication count a reflect of the number of papers published for each author, it does not mind if the papers are single authored or not. This is the way to detect the authors with highest number of papers published, giving a general view of the total production of each author.

There is not a specific section in WoS for CRM, or even for Business Analytics, so there is the need for refine the results by filtering and considering and/or dismissing the results depending on the main focus of the journals and the papers included on them. The Database "Web of Science Core Collection" is the core one for this study, included in the Web of Science. Currently there is no category like "Data mining" or "Business analytics" that may be the most fitting ones for this study research, so there is the need for looking for the best categories and searching areas to describe the study focus. Considering the subject in study, the interesting topics to select have been: "CRM" OR "Customer Relationship Management", that are the acronym and the complete name of the subject in study. Closing year 2017, the timespan for this study will be from 1900 to 2017, receiving a global amount of 10,038 results from Web of Science Core Collection related to these topics and timespan. The 2018 results will not be considered because there are still some of them being revised and for some months expected to be published, and that would made not consistent the static view of the global picture at the moment.

Considering the areas where Customer Relationship Management can be determinant main topic of study, further fine tuning has been to select the following refining categories in the left tree of Web of Science with a global amount of 3,543 results:

- $\quad$ BUSINESS $(1,245)$,

- MANAGEMENT (1,022),

- COMPUTER SCIENCE INFORMATION SYSTEMS $(1,020)$,

- OPERATIONS RESEARCH MANAGEMENT SCIENCE (576),

- COMPUTER SCIENCE THEORY METHODS (563),

- COMPUTER SCIENCE INTERDISCIPLINARY APPLICATIONS (547),

- $\quad$ ECONOMICS (338),

- INFORMATION SCIENCE LIBRARY SCIENCE (290),

- COMPUTER SCIENCE SOFTWARE ENGINEERING (248), 
Another important field for refining has been to select the Document Types interesting for this research: ARTICLE (1,646), REVIEW (35), NOTE (0), LETTER (4). The Results shown in the final research have been a global amount of 1,686.

\section{Results}

205

This section presents the main results found in WoS concerning the publishing journals in CRM research, the evolution of published papers, the most cited papers, the most prolific authors, institutions and countries.

\section{Publishing journals}

The most influential Journals or Source Titles in the CRM field are clearly EXPERT SYSTEMS WITH APPLICATIONS and JOURNAL OF MARKETING, assessed by the different variables considered in this study, mainly considering the h-index and number of papers with more than 100 citations. The second group of influence is composed by INDUSTRIAL MARKETING MANAGEMENT, JOURNAL OF THE ACADEMY OF MARKETING SCIENCE, DECISION SUPPORT SYSTEMS, and JOURNAL OF BUSINESS RESEARCH, again considering the h-index and the total number of papers published by them and their citations. The rest of the Journals are ranked in this study according to their influence. There are four columns showing the number of papers with more than 100, 50, 25 and 10 citations, as the way for considering the influence of each paper published in these journals.

In Table 1 there are shown the results of this research. EXPERT SYSTEMS WITH APPLICATIONS and JOURNAL OF MARKETING have published the most cited papers in CRM, especially considering the JOURNAL OF MARKETING that has the highest number of citations (4.885) despite of being the third one regarding published papers what makes for it the highest ratio of total citations per published paper $(143,68)$. The Journal or Source Title with highest number of published papers is EXPERT SYSTEMS WITH APPLICATIONS with 88.

Table 1. The 20 most influential CRM research journals according to WoS

\begin{tabular}{|c|c|c|c|c|c|c|c|c|c|c|c|}
\hline $\mathrm{R}$ & Name & $\mathrm{h}$ & TC & TP & TC/TP & $>100$ & $>50$ & $>25$ & $>10$ & IF & 5-IF \\
\hline 1 & $\begin{array}{l}\text { EXPERT SYSTEMS } \\
\text { WITH } \\
\text { APPLICATIONS }\end{array}$ & 32 & 3.094 & 88 & 35,16 & 6 & 17 & 42 & 69 & 3.768 & 3.711 \\
\hline 2 & $\begin{array}{ll}\text { JOURNAL } & \text { OF } \\
\text { MARKETING } & \end{array}$ & 29 & 4.885 & 34 & 143,68 & 16 & 23 & 30 & 32 & 7.338 & 9.592 \\
\hline 3 & $\begin{array}{l}\text { INDUSTRIAL } \\
\text { MARKETING } \\
\text { MANAGEMENT }\end{array}$ & 26 & 2.105 & 57 & 36,93 & 4 & 13 & 26 & 42 & 3.678 & 4.488 \\
\hline 4 & $\begin{array}{lr}\text { JOURNAL OF } & \text { THE } \\
\text { ACADEMY } & \text { OF } \\
\text { MARKETING } & \\
\text { SCIENCE } & \end{array}$ & 20 & 2.381 & 31 & 76,81 & 6 & 13 & 18 & 23 & 8.448 & 9.810 \\
\hline 5 & $\begin{array}{l}\text { DECISION } \\
\text { SUPPORT } \\
\text { SYSTEMS }\end{array}$ & 20 & 1.894 & 29 & 65,31 & 5 & 11 & 17 & 26 & 3.565 & 4.574 \\
\hline 6 & $\begin{array}{l}\text { JOURNAL } \\
\text { BUSINESS } \\
\text { RESEARCH }\end{array}$ & 19 & 1.446 & 33 & 43,82 & 4 & 10 & 14 & 25 & 2.509 & 3.689 \\
\hline 7 & $\begin{array}{l}\text { MARKETING } \\
\text { SCIENCE }\end{array}$ & 16 & 1.004 & 20 & 50,20 & 2 & 8 & 16 & 17 & 2.794 & 3.918 \\
\hline
\end{tabular}




\begin{tabular}{|c|c|c|c|c|c|c|c|c|c|c|c|c|}
\hline 8 & $\begin{array}{l}\text { JOURNAL } \\
\text { MARKETING } \\
\text { RESEARCH }\end{array}$ & DF & 15 & 1.516 & 21 & 72,19 & 3 & 9 & 12 & 16 & 3.854 & 5.678 \\
\hline 9 & $\begin{array}{l}\text { INDUSTRIAL } \\
\text { MANAGEMENT } \\
\text { DATA SYSTEMS }\end{array}$ & & 14 & 776 & 33 & 23,52 & 1 & 5 & 8 & 16 & 2.948 & 2.724 \\
\hline 10 & $\begin{array}{l}\text { MANAGEMENT } \\
\text { SCIENCE }\end{array}$ & & 14 & 578 & 19 & 30,42 & 0 & 2 & 11 & 16 & 3.544 & 4.927 \\
\hline 11 & $\begin{array}{l}\text { JOURNAL } \\
\text { INTERACTIVE } \\
\text { MARKETING }\end{array}$ & $\mathrm{DF}$ & 13 & 949 & 18 & 52,72 & 3 & 6 & 11 & 14 & 3.864 & 9.472 \\
\hline 12 & $\begin{array}{l}\text { JOURNAL } \\
\text { SERVICE } \\
\text { RESEARCH }\end{array}$ & $\mathrm{DF}$ & 13 & 1.547 & 18 & 85,94 & 3 & 8 & 11 & 14 & 6.842 & 7.099 \\
\hline 13 & $\begin{array}{l}\text { EUROPEAN } \\
\text { JOURNAL } \\
\text { MARKETING }\end{array}$ & $\mathrm{DF}$ & 11 & 569 & 19 & 29,95 & 2 & 2 & 6 & 12 & 1.497 & 2.545 \\
\hline 14 & $\begin{array}{l}\text { JOURNAL } \\
\text { BUSSINESS } \\
\text { INDUSTRIAL } \\
\text { MARKETING }\end{array}$ & $\begin{array}{l}\text { DF } \\
\&\end{array}$ & 10 & 333 & 29 & 11,48 & 0 & 1 & 3 & 9 & 1.833 & 2.062 \\
\hline 15 & $\begin{array}{l}\text { TOTAL QUALIT } \\
\text { MANAGEMENT } \\
\text { BUSINESS } \\
\text { EXCELLENCE }\end{array}$ & \& & 10 & 339 & 28 & 12,11 & 0 & 0 & 3 & 10 & 1.526 & 1.971 \\
\hline 16 & $\begin{array}{ll}\text { JOURNAL } & \text { O } \\
\text { SERVICES } & \\
\text { MARKETING } & \end{array}$ & $\mathrm{DF}$ & 10 & 313 & 20 & 15,65 & 0 & 1 & 3 & 10 & 2.408 & 2.817 \\
\hline 17 & $\begin{array}{l}\text { SERVICE } \\
\text { INDUSTRIES } \\
\text { JOURNAL }\end{array}$ & & 7 & 171 & 17 & 10,06 & 0 & 0 & 2 & 5 & 1.258 & 1.686 \\
\hline 18 & $\begin{array}{l}\text { LECTURE NOTE } \\
\text { IN COMPUTE } \\
\text { SCIENCE }\end{array}$ & & 6 & 192 & 37 & 5,19 & 0 & 1 & 1 & 4 & 0.402 & - \\
\hline 19 & $\begin{array}{l}\text { AFRICAN } \\
\text { JOURNAL } \\
\text { BUSINESS } \\
\text { MANAGEMENT }\end{array}$ & DF & 4 & 67 & 18 & 3,72 & 0 & 0 & 0 & 1 & 1.105 & 1.105 \\
\hline 20 & $\begin{array}{l}\text { MARKETING ANI } \\
\text { CONSUMER } \\
\text { BEHAVIOR: } \\
\text { CONCEPTS, } \\
\text { METHODOLOGIES } \\
\text { TOOLS, ANI } \\
\text { APPLICATION }\end{array}$ & & 0 & 0 & 23 & 0,00 & 0 & 0 & 0 & 0 & - & - \\
\hline
\end{tabular}

Abbreviations: $\mathrm{R}=$ Rank; Name $=$ Name of the Journal or Source Title $\mathrm{h}=\mathrm{h}$-index; $\mathrm{TC}=$ Total Citations; $\mathrm{TP}=$ Total Papers; TC/TP = ratio total Citations per Published Paper; $>100,>50,>25,>10=$ number of papers with more than 100, 50, 25, 10 citations; IF = Impact Factor 2017; 5-IF = five-year Impact Factor 2017.

The second influence group considers INDUSTRIAL MARKETING MANAGEMENT, JOURNAL OF THE ACADEMY OF MARKETING SCIENCE, DECISION SUPPORT SYSTEMS, and JOURNAL OF 
BUSINESS RESEARCH, all of them with pretty higher number of citations than the next influence group, but far from the two first ones. INDUSTRIAL MARKETING MANAGEMENT has the second highest number of published papers (57) even higher than the JOURNAL OF MARKETING mentioned above in the first influence group of Journals. On other hand, the JOURNAL OF THE ACADEMY OF MARKETING SCIENCE has the second globally highest ratio of total citations per published paper $(76,81)$. Important to say the four Journals included in this group, have higher ratio of total citations per published paper than the first ranked one EXPERT SYSTEMS WITH APPLICATIONS which has the highest number of published papers (88).

\section{Evolution of published articles}

As shown in Table 1, there are only 5 journals with at least 20 published papers about Customer Relationship Management, and only 7 Journals with more than 1.500 citations. That means that CRM has not a currently relevant position as research field in WoS.

Despite of not being a very common research field in WoS, Fig 1 shows that CRM is becoming an increasingly threated subject of research in the last decade. As it is shown in Fig 1, CRM started being studied in 1992 with only 1 testimonial article, and it was in year 2000 when it started the takeoff with 9 papers. It has doubled in 2001 with 21 papers, and it was growing with lineally progression until the 133 papers in 2011. Then the .com enterprises entered in a crisis period that made this research topic lineally decrease of interest until the 86 papers in 2014. The three last columns, corresponding to the last three years, show the impact and the influence of this topic as high potential research topic for nowadays, with 174 papers in 2015 , 164 papers in 2016, and 173 papers in 2017.

Total Publications
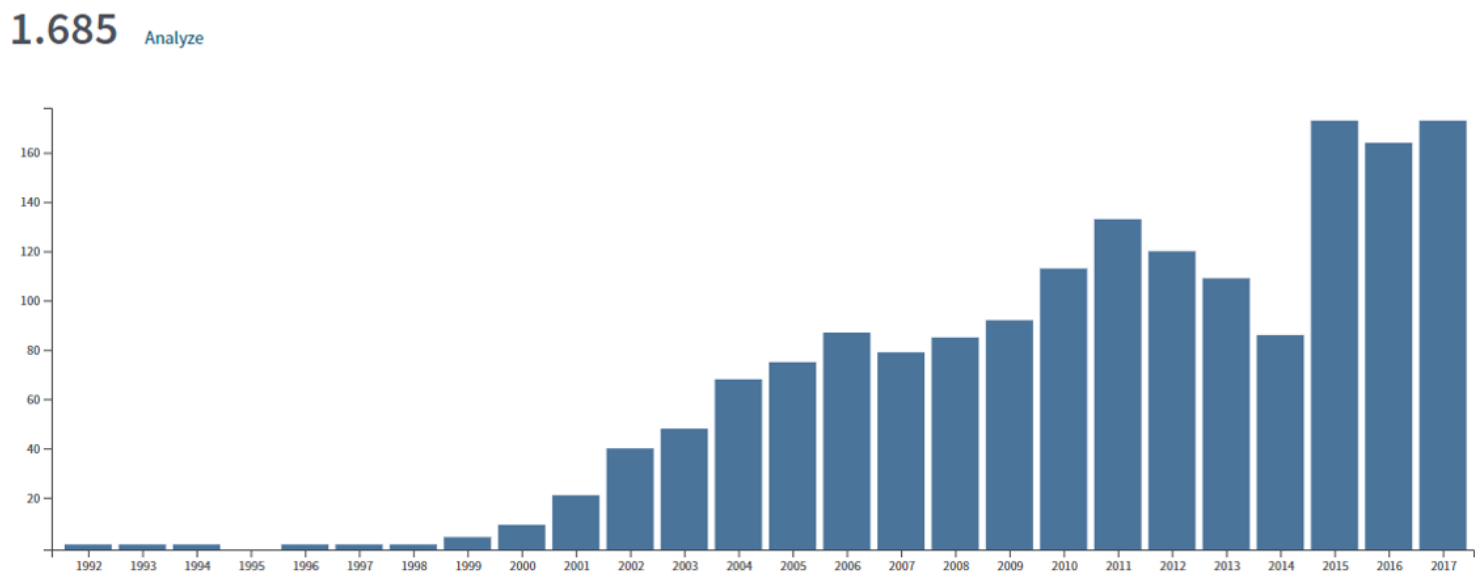

Fig 1. Number of annual publications in CRM in WoS (articles, letters, notes, and reviews) since 1900

On other hand, concerning number of citations, Fig 2 show how the papers on CRM started increasing the number of citations from the 1 citation in year 2000 until the 5.490 citations in 2017, again with a lineal progression that shows how the potential and influence of this research topic has become more and more important and relevant. 


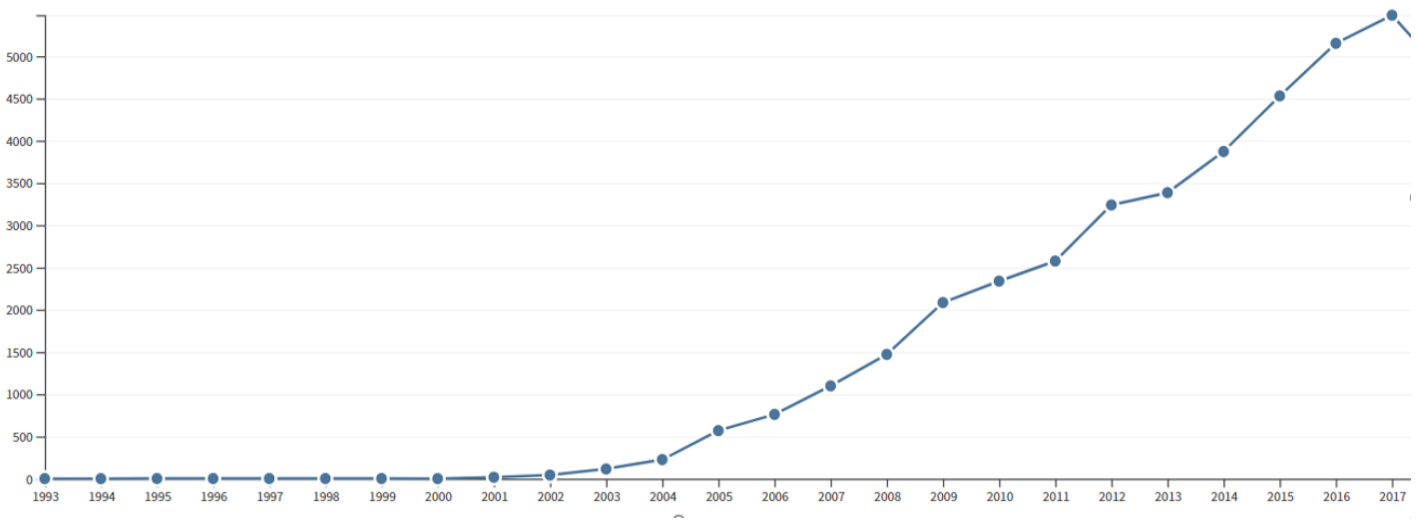

Fig 2. Number of annual citations in CRM in WoS (articles, letters, notes, and reviews) since 1900

Furthermore, if we look to the Table 2 the citation structure for the 1.685 considered papers, we can firstly see that the number of citations is very low compared to other disciplines where several papers receive more than 1.000 citations (Merigó et al., 2015). Other relevant conclusion is that it is worth studying only the period since year 2000 to 2017 , as the research results are nearly the same that in all time period research. Furthermore, it is clear that most of the papers receive less than 50 citations ( 1.3334 papers that makes the $80 \%$ of the global studied 1.685 results).

Table 2. General citation structure in CRM research in WoS

\begin{tabular}{lllll}
\hline & All time & \multicolumn{3}{c}{$2000-2017$} \\
\cline { 2 - 5 } Citations & Number of papers & $\%$ Papers & Number of papers & $\%$ Papers \\
\hline$>500$ citations & 4 & 0,237 & 4 & 0,239 \\
$>200$ citations & 32 & 1,899 & 31 & 1,851 \\
$>100$ citations & 88 & 5,223 & 86 & 5,134 \\
$>50$ citations & 227 & 13,472 & 224 & 13,373 \\
$<=50$ citations & 1.334 & 79,169 & 1330 & 79,403 \\
\hline Total & 1.685 & 100,000 & 1675 & 100,000 \\
\hline
\end{tabular}

\section{The most influential articles in CRM research of all time}

Over the last decade, more widely since year 2000, many influential papers have been published in CRM research. Table 4 shows a list with the 50 most cited papers in CRM of all time. Analyzing this table there is a clear view on which are the most influential papers in CRM research.

The Journal of Marketing has 13 papers in the list, being the journal with highest number of papers in the list. Next there are two journals with 4 papers each one in the list, namely Journal of the Academy of Marketing Science, and Decision Support Systems. With 3 papers in the list there are several journals or source types: Expert Systems with Applications, Industrial Marketing Management, Journal of Service Research, and MIS Quaterly.

The most cited paper of all time in CRM research in the list, was published in 2003 by Burnham, Frels, and Mahajan, with 592 citations currently. There are three other papers that have also received more than 500 citations: the second one was published by Reinartz, Krafft, and Hoyer in 2004, the third one by Payne and Frow in 2005, and the fourth one by Verhoef in 2003. 
280

281

282

283

284

285

The study has also considered the number of citations per year, as way to discriminate the results depending not only in the absolute amount of citations, but also in the relative amount of citations per year. The paper with highest amount of citations per year was published by Brodie, Hollebeek, Juric, and Ilic in 2011, with 59,50 citations per year. The second most citated paper per year was published by $\mathrm{Lu}, \mathrm{Wu}, \mathrm{Mao}$ et al. in 2015, with 44,75 citations per year currently. 


\begin{tabular}{|c|c|c|c|c|c|c|c|}
\hline Journal & & $\mathrm{R}$ & TC & Title & Author/s & Year & $\mathrm{C} / \mathrm{Y}$ \\
\hline $\begin{array}{l}\text { JOURNAL OF } \\
\text { ACADEMY } \\
\text { MARKETING } \\
\text { SCIENCE }\end{array}$ & $\begin{array}{r}\text { THE } \\
\text { OF }\end{array}$ & 1 & 592 & $\begin{array}{l}\text { Consumer switching costs: A typology, antecedents, and } \\
\text { consequences }\end{array}$ & $\begin{array}{l}\text { Burnham, } \\
\text { JK; Mahajan, V }\end{array}$ & 2003 & 37,00 \\
\hline $\begin{array}{l}\text { JOURNAL } \\
\text { MARKETING } \\
\text { RESEARCH }\end{array}$ & $\mathrm{OF}$ & 2 & 584 & $\begin{array}{l}\text { The customer relationship management process: Its measurement } \\
\text { and impact on performance }\end{array}$ & $\begin{array}{l}\text { Reinartz, W; Krafft, M; } \\
\text { Hoyer, WD }\end{array}$ & 2004 & 38,93 \\
\hline $\begin{array}{l}\text { JOURNAL } \\
\text { MARKETING }\end{array}$ & OF & 3 & 538 & A strategic framework for customer relationship management & Payne, A; Frow, P & 2005 & 38,43 \\
\hline $\begin{array}{l}\text { JOURNAL } \\
\text { MARKETING }\end{array}$ & OF & 4 & 504 & $\begin{array}{l}\text { Understanding the effect of customer relationship management } \\
\text { efforts on customer retention and customer share development }\end{array}$ & Verhoef, PC & 2003 & 31,50 \\
\hline $\begin{array}{l}\text { DATA } \\
\text { KNOWLEDGE } \\
\text { ENGINEERING }\end{array}$ & $\&$ & 5 & 480 & Workflow mining: A survey of issues and approaches & $\begin{array}{l}\text { Van der Aalst, WMP; Van } \\
\text { Dongen, } \\
\text { J; Maruster, }\end{array}$ & 2003 & 30,00 \\
\hline $\begin{array}{l}\text { JOURNAL } \\
\text { SERVICE } \\
\text { RESEARCH }\end{array}$ & OF & 6 & 476 & $\begin{array}{l}\text { Customer Engagement: Conceptual Domain, Fundamental } \\
\text { Propositions, and Implications for Research }\end{array}$ & $\begin{array}{l}\text { Brodie, } \quad \text { Roderick } \\
\text { J.; Hollebeek, Linda D.; Juric, } \\
\text { Biljan; Ilic, Ana }\end{array}$ & 2011 & 59,50 \\
\hline $\begin{array}{l}\text { DECISION SUPF } \\
\text { SYSTEMS }\end{array}$ & ORT & 7 & 428 & $\begin{array}{l}\text { An empirical analysis of the antecedents of electronic commerce } \\
\text { service continuance }\end{array}$ & Bhattacherjee, A & 2001 & 23,78 \\
\hline $\begin{array}{l}\text { JOURNAL } \\
\text { MARKETING }\end{array}$ & $\mathrm{OF}$ & 8 & 394 & $\begin{array}{l}\text { Marketing, business processes, and shareholder value: An } \\
\text { organizationally embedded view of marketing activities and the } \\
\text { discipline of marketing }\end{array}$ & $\begin{array}{l}\text { Srivastava, RK; Shervani, } \\
\text { TA; Fahey, L }\end{array}$ & 1999 & 19,70 \\
\hline $\begin{array}{l}\text { EXPERT SYST } \\
\text { WITH } \\
\text { APPLICATIONS }\end{array}$ & EMS & 9 & 330 & $\begin{array}{l}\text { Application of data mining techniques in customer relationship } \\
\text { management: A literature review and classification }\end{array}$ & $\begin{array}{l}\text { Ngai, E. W. T.; Xiu, Li; Chau, } \\
\text { D. C. K. }\end{array}$ & 2009 & 33,00 \\
\hline $\begin{array}{l}\text { JOURNAL } \\
\text { MARKETING }\end{array}$ & $\mathrm{OF}$ & 10 & 322 & $\begin{array}{l}\text { A customer relationship management roadmap: What is known, } \\
\text { potential pitfalls, and where to go }\end{array}$ & $\begin{array}{l}\text { Boulding, W; Staelin, R; } \\
\text { Ehret, M; Johnston, WJ }\end{array}$ & 2005 & 23,00 \\
\hline $\begin{array}{l}\text { JOURNAL } \\
\text { MARKETING }\end{array}$ & OF & 11 & 322 & $\begin{array}{l}\text { The role of relational information processes and technology use } \\
\text { in customer relationship management }\end{array}$ & $\begin{array}{l}\text { Jayachandran, S; Sharma, } \\
\text { S; Kaufman, P; Raman, P }\end{array}$ & 2005 & 23,00 \\
\hline $\begin{array}{l}\text { JOURNAL } \\
\text { MARKETING }\end{array}$ & OF & 12 & 321 & $\begin{array}{l}\text { The influence of cause-related marketing on consumer choice: } \\
\text { Does one good turn deserve another? }\end{array}$ & $\begin{array}{l}\text { Barone, MJ; Miyazaki, AD; } \\
\text { Taylor, KA }\end{array}$ & 2000 & 16,89 \\
\hline
\end{tabular}




\begin{tabular}{|c|c|c|c|c|c|c|c|}
\hline $\begin{array}{l}\text { JOURNAL } \\
\text { SERVICE } \\
\text { RESEARCH }\end{array}$ & $\mathrm{OF}$ & 13 & 280 & $\begin{array}{l}\text { Challenges and opportunities in multichannel customer } \\
\text { management }\end{array}$ & $\begin{array}{l}\text { Neslin, Scott A.; Grewal, } \\
\text { Dhruv; Leghorn, Robert; et al. }\end{array}$ & 2005 & 21,54 \\
\hline $\begin{array}{l}\text { JOURNAL } \\
\text { BUSINESS } \\
\text { RESEARCH }\end{array}$ & $\mathrm{OF}$ & 14 & 273 & $\begin{array}{l}\text { The effect of web interface features on consumer online purchase } \\
\text { intentions }\end{array}$ & $\begin{array}{l}\text { Hausman, Angela V.; Siekpe, } \\
\text { Jeffirey Sam }\end{array}$ & 2009 & 27,30 \\
\hline $\begin{array}{l}\text { JOURNAL } \\
\text { OPERATIONS } \\
\text { MANAGEMENT }\end{array}$ & $\mathrm{OF}$ & 15 & 273 & $\begin{array}{l}\text { The impact of enterprise systems on corporate performance: A } \\
\text { study of ERP, SCM, and CRM system implementations }\end{array}$ & $\begin{array}{l}\text { Hendricks, Kevin B.; Singhal, } \\
\text { Vinod R.; Stratman, Jeff K. }\end{array}$ & 2007 & 22,75 \\
\hline $\begin{array}{l}\text { JOURNAL } \\
\text { MARKETING }\end{array}$ & OF & 16 & 261 & $\begin{array}{l}\text { Why do customer relationship management applications affect } \\
\text { customer satisfaction? }\end{array}$ & $\begin{array}{l}\text { Mithas, } \\
\text { MS; Fornell, C }\end{array}$ & 2005 & 18,64 \\
\hline $\begin{array}{l}\text { INFORMATION } \\
\text { SYSTEMS }\end{array}$ & & 17 & 252 & Business process mining: An industrial application & $\begin{array}{l}\text { van der Aalst, W. M. } \\
\text { P.; Reijers, H. A.; Weijters, } \\
\text { A. J. M. M.; et al. }\end{array}$ & 2007 & 21,00 \\
\hline $\begin{array}{l}\text { CALIFORNIA } \\
\text { MANAGEMENT } \\
\text { REVIEW }\end{array}$ & & 18 & 248 & A framework for customer relationship management & Winer, RS & 2001 & 13,78 \\
\hline $\begin{array}{l}\text { JOURNAL } \\
\text { MARKETING }\end{array}$ & $\mathrm{OF}$ & 19 & 247 & Interaction orientation and firm performance & Ramani, Girish; Kumar, V. & 2008 & 22,45 \\
\hline $\begin{array}{l}\text { HARVARD } \\
\text { BUSINESS REVIEV }\end{array}$ & & 20 & 243 & Understanding customer experience & $\begin{array}{l}\text { Meyer, } \\
\text { Christopher; Schwager, } \\
\text { Andre }\end{array}$ & 2007 & 20,25 \\
\hline $\begin{array}{l}\text { JOURNAL OF } \\
\text { ACADEMY } \\
\text { MARKETING } \\
\text { SCIENCE }\end{array}$ & $\begin{array}{r}\text { THE } \\
\text { OF }\end{array}$ & 21 & 238 & $\begin{array}{l}\text { How can corporate social responsibility activities create value for } \\
\text { stakeholders? A systematic review }\end{array}$ & Peloza, John; Shang, Jingzhi & 2011 & 29,75 \\
\hline $\begin{array}{l}\text { HARVARD } \\
\text { BUSINESS REVIEV }\end{array}$ & & 22 & 236 & Avoid the four perils of CRM & $\begin{array}{l}\text { Rigby, DK; Reichheld, } \\
\text { FF; Schefter, P }\end{array}$ & 2002 & 13,88 \\
\hline $\begin{array}{l}\text { JOURNAL } \\
\text { MARKETING }\end{array}$ & $\mathrm{OF}$ & 23 & 230 & The Role of Customer Gratitude in Relationship Marketing & $\begin{array}{l}\text { Palmatier, Robert W.; Jarvis, } \\
\text { Cheryl Burke; Bechkoff, } \\
\text { Jennifer R.; et al. }\end{array}$ & 2009 & 23,00 \\
\hline $\begin{array}{l}\text { JOURNAL } \\
\text { PRODUCT } \\
\text { INNOVATION } \\
\text { MANAGEMENT }\end{array}$ & $\mathrm{OF}$ & 24 & 228 & $\begin{array}{l}\text { Virtual Customer Environments: Testing a Model of Voluntary } \\
\text { Participation in Value Co-creation Activities }\end{array}$ & $\begin{array}{l}\text { Nambisan, Satish; Baron, } \\
\text { Robert A. }\end{array}$ & 2009 & 22,80 \\
\hline
\end{tabular}




\begin{tabular}{|c|c|c|c|c|c|c|c|}
\hline $\begin{array}{l}\text { JOURNAL } \\
\text { SERVICE } \\
\text { RESEARCH }\end{array}$ & OF & 25 & 221 & $\begin{array}{l}\text { Customer Engagement as a New Perspective in Customer } \\
\text { Management }\end{array}$ & $\begin{array}{l}\text { Verhoef, Peter C.; Reinartz, } \\
\text { Werner J.; Krafft, Manfred }\end{array}$ & 2010 & 24,56 \\
\hline $\begin{array}{l}\text { JOURNAL } \\
\text { MARKETING }\end{array}$ & $\mathrm{OF}$ & 26 & 220 & $\begin{array}{l}\text { Dynamic customer relationship management: Incorporating } \\
\text { future considerations into the service retention decision }\end{array}$ & $\begin{array}{l}\text { Lemon, } \\
\text { TB; Winer, RS }\end{array}$ & 2002 & 12,94 \\
\hline $\begin{array}{l}\text { DECISION SUPPC } \\
\text { SYSTEMS }\end{array}$ & & 27 & 213 & Knowledge management and data mining for marketing & $\begin{array}{l}\text { Shaw, MJ; Subramaniam, } \\
\text { C; Tan, GW; et al. }\end{array}$ & 2001 & 11,83 \\
\hline $\begin{array}{l}\text { JOURNAL } \\
\text { INTERACTIVE } \\
\text { MARKETING }\end{array}$ & $\mathrm{OF}$ & 28 & 207 & $\begin{array}{l}\text { Interactions in virtual customer environments: Implications for } \\
\text { product support and customer relationship management }\end{array}$ & $\begin{array}{l}\text { Nambisan, } \\
\text { Robert A. }\end{array}$ & 2007 & 17,25 \\
\hline MIS QUARTERLY & & 29 & 207 & $\begin{array}{l}\text { Reconceptualizing compatibility beliefs in technology acceptance } \\
\text { research }\end{array}$ & $\begin{array}{l}\text { Karahanna, Elena; Agarwal, } \\
\text { Ritu; Angst, Corey M. }\end{array}$ & 2006 & 15,92 \\
\hline $\begin{array}{l}\text { JOURNAL } \\
\text { RETAILING }\end{array}$ & $\mathrm{OF}$ & 30 & 207 & $\begin{array}{l}\text { Building and sustaining profitable customer loyalty for the } 21 \mathrm{st} \\
\text { century }\end{array}$ & Kumar, V; Shah, D & 2004 & 13,80 \\
\hline $\begin{array}{l}\text { JOURNAL } \\
\text { ADVERTISING }\end{array}$ & $\mathrm{OF}$ & 31 & 206 & $\begin{array}{l}\text { Consumer responses to corporate social responsibility (CSR) } \\
\text { initiatives - Examining the role of brand-cause fit in cause-related } \\
\text { marketing }\end{array}$ & Nan, Xiaoli; Heo, Kwangjun & 2007 & 17,17 \\
\hline $\begin{array}{l}\text { INDUSTRIAL } \\
\text { MARKETING } \\
\text { MANAGEMENT }\end{array}$ & & 32 & 203 & $\begin{array}{l}\text { An evaluation of divergent perspectives on customer relations hip } \\
\text { management: Towards a common understanding of an emerging } \\
\text { phenomenon }\end{array}$ & $\begin{array}{l}\text { Zablah, AR; Bellenger, } \\
\text { DN; Johnston, WJ }\end{array}$ & 2004 & 13,53 \\
\hline $\begin{array}{l}\text { MARKETING } \\
\text { SCIENCE }\end{array}$ & & 33 & 192 & Marketing models of service and relationships & $\begin{array}{l}\text { Rust, Roland T.; Chung, Tuck } \\
\text { Siong }\end{array}$ & 2006 & 14,77 \\
\hline $\begin{array}{l}\text { JOURNAL } \\
\text { MARKETING }\end{array}$ & $\mathrm{OF}$ & 34 & 183 & $\begin{array}{l}\text { The hidden minefields in the adoption of sales force automation } \\
\text { technologies }\end{array}$ & Speier, C; Venkatesh, V & 2002 & 10,76 \\
\hline $\begin{array}{l}\text { DECISION SUPPC } \\
\text { SYSTEMS }\end{array}$ & ORT & 35 & 179 & Recommender system application developments: A survey & $\begin{array}{l}\text { Lu, Jie; Wu, } \\
\text { Dianshuang; Mao, Mingsong; } \\
\text { et al. }\end{array}$ & 2015 & 44,75 \\
\hline $\begin{array}{l}\text { JOURNAL OF } \\
\text { ACADEMY } \\
\text { MARKETING } \\
\text { SCIENCE }\end{array}$ & $\begin{array}{r}\text { THE } \\
\text { OF }\end{array}$ & 36 & 179 & $\begin{array}{l}\text { Customer relationship dynamics: Service quality and customer } \\
\text { loyalty in the context of varying levels of customer expertise and } \\
\text { switching costs }\end{array}$ & Bell, SJ; Auh, S; Smalley, K & 2005 & 12,79 \\
\hline $\begin{array}{l}\text { JOURNAL } \\
\text { INTERACTIVE } \\
\text { MARKETING }\end{array}$ & $\mathrm{OF}$ & 37 & 178 & $\begin{array}{l}\text { Key Issues in Multichannel Customer Management: Current } \\
\text { Knowledge and Future Directions }\end{array}$ & $\begin{array}{l}\text { Neslin, Scott A.; Shankar, } \\
\text { Venkatesh }\end{array}$ & 2009 & 17,80 \\
\hline
\end{tabular}




\begin{tabular}{|c|c|c|c|c|c|c|}
\hline $\begin{array}{l}\text { JOURNAL } \\
\text { MARKETING }\end{array}$ & 38 & 177 & $\begin{array}{l}\text { Is Market Orientation a Source of Sustainable Competitive } \\
\text { Advantage or Simply the Cost of Competing? }\end{array}$ & $\begin{array}{l}\text { Kumar, } \quad \text { V.; Jones, } \\
\text { Eli; Venkatesan, Rajkumar; et } \\
\text { al. }\end{array}$ & 2011 & 22,13 \\
\hline $\begin{array}{l}\text { JOURNAL } \\
\text { MARKETING } \\
\text { RESEARCH }\end{array}$ & 39 & 175 & Customer channel migration & $\begin{array}{l}\text { Ansari, Asim; Mela, Carl } \\
\text { F.; Neslin, Scott A. }\end{array}$ & 2008 & 15,91 \\
\hline MIS QUARTERLY & 40 & 169 & $\begin{array}{l}\text { HOW INFORMATION MANAGEMENT } \\
\text { INFLUENCES FIRM PERFORMANCE }\end{array}$ & $\begin{array}{l}\text { Mithas, Sunil; Ramasubbu, } \\
\text { Narayan; Sambamurthy, V. }\end{array}$ & 2011 & 21,13 \\
\hline $\begin{array}{l}\text { INDUSTRIAL } \\
\text { MARKETING } \\
\text { MANAGEMENT }\end{array}$ & 41 & 168 & $\begin{array}{l}\text { Demand chain management-integrating marketing and supply } \\
\text { chain management }\end{array}$ & $\begin{array}{l}\text { Juttner, Uta; Christopher, } \\
\text { Martin; Baker, Susan }\end{array}$ & 2007 & 14,00 \\
\hline $\begin{array}{l}\text { EUROPEAN } \\
\text { JOURNAL } \\
\text { MARKETING }\end{array}$ & 42 & 161 & $\begin{array}{l}\text { Role of electronic trust in online retailing - A re-examination of } \\
\text { the commitment-trust theory }\end{array}$ & $\begin{array}{l}\text { Mukherjee, Avinandan; Nath, } \\
\text { Prithwiraj }\end{array}$ & 2007 & 13,42 \\
\hline $\begin{array}{l}\text { JOURNAL } \\
\text { MARKETING }\end{array}$ & 43 & 155 & $\begin{array}{l}\text { The long-term impact of loyalty programs on consumer purchase } \\
\text { behavior and loyalty }\end{array}$ & Liu, Yuping & 2007 & 12,92 \\
\hline $\begin{array}{l}\text { EXPERT SYSTEMS } \\
\text { WITH } \\
\text { APPLICATIONS }\end{array}$ & 44 & 154 & $\begin{array}{l}\text { Churn prediction in subscription services: An application of } \\
\text { support vector machines while comparing two parameter- } \\
\text { selection techniques }\end{array}$ & $\begin{array}{l}\text { Coussement, Kristof; Van den } \\
\text { Poel, Dirk }\end{array}$ & 2008 & 14,00 \\
\hline $\begin{array}{l}\text { JOURNAL } \\
\text { BUSINESS } \\
\text { RESEARCH }\end{array}$ & 45 & 151 & $\begin{array}{l}\text { The role of brand/cause fit in the effectiveness of cause-related } \\
\text { marketing campaigns }\end{array}$ & Pracejus, JW; Olsen, GD & 2004 & 10,07 \\
\hline MIS QUARTERLY & 46 & 149 & $\begin{array}{l}\text { INTERFIRM STRATEGIC INFORMATION FLOWS IN } \\
\text { LOGISTICS SUPPLY CHAIN RELATIONSHIPS }\end{array}$ & Klein, Richard; Rai, Arun & 2009 & 14,90 \\
\hline $\begin{array}{l}\text { EXPERT SYSTEMS } \\
\text { WITH } \\
\text { APPLICATIONS }\end{array}$ & 47 & 149 & $\begin{array}{l}\text { An LTV model and customer segmentation based on customer } \\
\text { value: a case study on the wireless telecommunication industry }\end{array}$ & Hwang, H; Jung, T; Suh, E & 2004 & 9,93 \\
\hline $\begin{array}{l}\text { DECISION SUPPORT } \\
\text { SYSTEMS }\end{array}$ & 48 & 148 & $\begin{array}{l}\text { Identification of influencers - Measuring influence in customer } \\
\text { networks }\end{array}$ & Christine; Bichler, & 2008 & 13,45 \\
\hline $\begin{array}{l}\text { INDUSTRIAL } \\
\text { MARKETING } \\
\text { MANAGEMENT }\end{array}$ & 49 & 148 & $\begin{array}{l}\text { Creating customer knowledge competence: managing customer } \\
\text { relationship management programs strategically }\end{array}$ & Campbell, AJ & 2003 & 9,25 \\
\hline
\end{tabular}


JOURNAL OF THE 50 146 The differing and mediating roles of trust and relationship Aurier,

ACADEMY

commitment

in service

relationship

development

RKETING

Abbreviations are available in Table 1 except for $\mathrm{C} / \mathrm{Y}=$ Citations per Year 


\section{The most prolific and influential authors}

288 Regarding the study of the most influential authors in Customer Relationship Management research, table 4 presents the 50 authors that have received the highest number of citations.

290 Verhoef P.C. is the author with the highest number of citations, appearing not far from him two more authors 291 with more than 1.000 citations. These two authors are, in second position Van den Poel D., and the third Kumar V. The fourth author is Krafft, with less than 1.000 citatiosn but almost on the border of that point of cut.

294 Regarding the precedence of the most productive and influential authors, interesting to say that the most of them come from USA (14 authors in a list of 50). The second and third Country regarding influential authors, are Taiwan and UK (represented in the list by Wales and England), both with 6 appearances.

Table 4. The 50 most productive and influential authors in CRM research

\begin{tabular}{|c|c|c|c|c|c|c|c|c|c|c|}
\hline $\mathrm{R}$ & Author name & Institution & Country & $\mathrm{TP}$ & $\mathrm{TC}$ & $\begin{array}{l}\mathrm{TC} / \mathrm{T} \\
\mathrm{P}\end{array}$ & $\mathrm{h}$ & $\begin{array}{l}>= \\
100\end{array}$ & $>=50$ & $\begin{array}{l}>= \\
20\end{array}$ \\
\hline 1 & $\begin{array}{l}\text { VERHOEF } \\
\text { PC }\end{array}$ & Univ Groningen & Netherlands & 18 & 1.690 & 93,89 & 14 & 4 & 10 & 14 \\
\hline 2 & $\begin{array}{l}\text { VAN DEN } \\
\text { POEL D }\end{array}$ & Univ Ghent & Belgium & 31 & 1.431 & 46,16 & 21 & 4 & 11 & 22 \\
\hline 3 & KUMAR V & $\begin{array}{l}\text { Georgia State } \\
\text { Univ }\end{array}$ & USA & 20 & 1.100 & 55,00 & 14 & 3 & 6 & 14 \\
\hline 4 & KRAFFT M & Univ Munster & Germany & 7 & 953 & $\begin{array}{l}136,1 \\
4\end{array}$ & 6 & 2 & 4 & 5 \\
\hline 5 & NESLIN SA & $\begin{array}{l}\text { Tuck } \\
\text { Business } \\
\text { Dartmouth }\end{array}$ & USA & 8 & 747 & 93,38 & 8 & 3 & 3 & 6 \\
\hline 6 & FROW P & Univ Sydney & Australia & 5 & 688 & $\begin{array}{l}137,6 \\
0\end{array}$ & 4 & 1 & 2 & 3 \\
\hline 7 & PAYNE A & $\begin{array}{l}\text { Univ New South } \\
\text { Wales }\end{array}$ & Australia & 5 & 688 & $\begin{array}{l}137,6 \\
0\end{array}$ & 4 & 1 & 2 & 3 \\
\hline 8 & $\begin{array}{l}\text { PALMATIER } \\
\text { RW }\end{array}$ & Univ Washington & USA & 6 & 610 & $\begin{array}{l}101,6 \\
7\end{array}$ & 5 & 3 & 5 & 5 \\
\hline 9 & $\begin{array}{l}\text { JOHNSTON } \\
\text { WJ }\end{array}$ & $\begin{array}{l}\text { Georgia } \\
\text { Univ }\end{array}$ & USA & 5 & 547 & $\begin{array}{l}109,4 \\
0\end{array}$ & 4 & 2 & 2 & 2 \\
\hline 10 & THOMAS JS & $\begin{array}{l}\text { So } \quad \text { Methodist } \\
\text { Univ }\end{array}$ & USA & 5 & 529 & $\begin{array}{l}105,8 \\
0\end{array}$ & 5 & 2 & 4 & 4 \\
\hline 11 & $\begin{array}{l}\text { VENKATES } \\
\text { AN R }\end{array}$ & Univ Virginia & USA & 10 & 519 & 51,90 & 9 & 1 & 5 & 8 \\
\hline 12 & JONES E & $\begin{array}{l}\text { Louisiana State } \\
\text { Univ }\end{array}$ & USA & 4 & 425 & $\begin{array}{l}106,2 \\
5\end{array}$ & 4 & 2 & 4 & 4 \\
\hline 13 & LEMON KN & Boston Coll & USA & 5 & 407 & 81,40 & 5 & 1 & 3 & 4 \\
\hline 14 & RUST RT & Univ Maryland & USA & 6 & 404 & 67,33 & 5 & 1 & 3 & 5 \\
\hline 15 & $\begin{array}{l}\text { LARIVIERE } \\
\text { B }\end{array}$ & State Univ Ghent & Belgium & 4 & 307 & 76,75 & 4 & 2 & 3 & 3 \\
\hline 16 & $\begin{array}{l}\text { COUSSEME } \\
\text { NT K }\end{array}$ & $\begin{array}{l}\text { Univ Catholique } \\
\text { Lille }\end{array}$ & France & 4 & 267 & 66,75 & 4 & 1 & 2 & 4 \\
\hline 17 & $\begin{array}{l}\text { HOMBURG } \\
\mathrm{C}\end{array}$ & Univ Mannheim & Germany & 4 & 257 & 64,25 & 4 & 0 & 2 & 4 \\
\hline
\end{tabular}




\begin{tabular}{|c|c|c|c|c|c|c|c|c|c|}
\hline 18 & YEN DC & Miami Univ & USA & 5 & 255 & 51,00 & 5 & 0 & 2 \\
\hline 19 & PRINZIE A & Univ Ghent & Belgium & 8 & 241 & 30,13 & 7 & 0 & 1 \\
\hline 20 & RYALS L & Cranfield Univ & England & 5 & 221 & 44,20 & 5 & 1 & 1 \\
\hline 21 & LEE WB & $\begin{array}{l}\text { Hong Kong } \\
\text { Polytech Univ }\end{array}$ & $\begin{array}{l}\text { Peoples } \\
\text { China }\end{array}$ & 6 & 209 & 34,83 & 6 & 0 & 1 \\
\hline 22 & CHOY KL & $\begin{array}{l}\text { Hong Kong } \\
\text { Polytech Univ }\end{array}$ & $\begin{array}{l}\text { Peoples } \\
\text { China }\end{array}$ & 7 & 205 & 29,29 & 6 & 0 & 1 \\
\hline 23 & $\begin{array}{l}\text { MALTHOUS } \\
\text { E EC }\end{array}$ & $\begin{array}{l}\text { Northwestern } \\
\text { Univ }\end{array}$ & USA & 5 & 205 & 41,00 & 3 & 1 & 2 \\
\hline 24 & $\begin{array}{l}\text { BRADLOW } \\
\text { ET }\end{array}$ & Univ Penn & USA & 4 & 183 & 45,75 & 4 & 0 & 1 \\
\hline 25 & $\begin{array}{l}\text { HAENLEIN } \\
\mathrm{M}\end{array}$ & ESCP Europe & France & 5 & 166 & 33,20 & 3 & 1 & 1 \\
\hline 26 & SOHN SY & Yonsei Univ & South Korea & 7 & 131 & 18,71 & 5 & 0 & 1 \\
\hline 27 & $\begin{array}{l}\text { SCHWEIDEL } \\
\text { DA }\end{array}$ & Emory Univ & USA & 5 & 128 & 25,60 & 4 & 0 & 0 \\
\hline 28 & CHANG HH & $\begin{array}{l}\text { Natl Cheng Kung } \\
\text { Univ }\end{array}$ & Taiwan & 5 & 121 & 24,20 & 4 & 0 & 1 \\
\hline 29 & KNOX S & Cranfield Univ & England & 5 & 112 & 22,40 & 5 & 0 & 0 \\
\hline 30 & $\begin{array}{l}\text { BIJMOLT } \\
\text { THA }\end{array}$ & Univ Groningen & Netherlands & 5 & 109 & 21,80 & 4 & 0 & 1 \\
\hline 31 & $\begin{array}{l}\text { LAMBERT } \\
\text { DM }\end{array}$ & Ohio State Univ & USA & 4 & 108 & 27,00 & 4 & 0 & 0 \\
\hline 32 & MAKLAN S & Cranfield Univ & England & 5 & 103 & 20,60 & 5 & 0 & 0 \\
\hline 33 & CHEN YS & $\begin{array}{l}\text { Hwa Hsia Univ } \\
\text { Technol }\end{array}$ & Taiwan & 4 & 101 & 25,25 & 2 & 1 & 1 \\
\hline 34 & $\begin{array}{l}\text { KERAMATI } \\
\text { A }\end{array}$ & Univ Tehran & Iran & 4 & 78 & 19,50 & 3 & 0 & 0 \\
\hline 35 & CHEN YH & $\begin{array}{l}\text { Natl Cheng Kung } \\
\text { Univ }\end{array}$ & Taiwan & 4 & 65 & 16,25 & 2 & 0 & 1 \\
\hline 36 & HA SH & $\begin{array}{l}\text { Kyungpook Natl } \\
\text { Univ }\end{array}$ & South Korea & 5 & 52 & 10,40 & 3 & 0 & 1 \\
\hline 37 & TERHO H & Univ Turku & Finland & 6 & 46 & 7,67 & 4 & 0 & 0 \\
\hline 38 & VERBANO C & Univ Padua & Italy & 5 & 40 & 8,00 & 3 & 0 & 0 \\
\hline 39 & CHANG CT & Aletheia Univ & Taiwan & 4 & 40 & 10,00 & 4 & 0 & 0 \\
\hline 40 & CHIANG WY & Aletheia Univ & Taiwan & 4 & 40 & 10,00 & 4 & 0 & 0 \\
\hline 41 & BAECKE P & Univ Ghent & Belgium & 4 & 36 & 9,00 & 3 & 0 & 0 \\
\hline 42 & KIM J & $\begin{array}{l}\text { Sejong Cyber } \\
\text { Univ }\end{array}$ & South Korea & 5 & 35 & 7,00 & 3 & 0 & 0 \\
\hline 43 & DOERR M & $\begin{array}{l}\text { Fdn Res \& } \\
\text { Technol Hellas }\end{array}$ & Greece & 4 & 32 & 8,00 & 3 & 0 & 0 \\
\hline 44 & KU ECS & $\begin{array}{l}\text { Natl Kaohsiung } \\
\text { Univ }\end{array}$ & Taiwan & 4 & 25 & 6,25 & 3 & 0 & 0 \\
\hline 45 & CREMA M & Univ Padua & Italy & 4 & 18 & 4,50 & 2 & 0 & 0 \\
\hline 46 & TUDHOPE D & Univ South Wales & Wales & 6 & 14 & 2,33 & 3 & 0 & 0 \\
\hline 47 & $\begin{array}{l}\text { NICCOLUCC } \\
\text { I F }\end{array}$ & PIN & Italy & 5 & 12 & 2,40 & 2 & 0 & 0 \\
\hline
\end{tabular}




\begin{tabular}{|c|c|c|c|c|c|c|c|c|c|c|}
\hline 48 & $\begin{array}{l}\text { VLACHIDIS } \\
\text { A }\end{array}$ & Univ South Wales & Wales & 5 & 11 & 2,20 & 2 & 0 & 0 & 0 \\
\hline 49 & BINDING C & Univ South Wales & Wales & 4 & 9 & 2,25 & 2 & 0 & 0 & 0 \\
\hline 50 & $\begin{array}{l}\text { KHASAWNE } \\
\text { H R }\end{array}$ & $\begin{array}{l}\text { Jordan Univ Sci } \\
\& \text { Technol }\end{array}$ & Jordan & 4 & 0 & 0,00 & 0 & 0 & 0 & 0 \\
\hline
\end{tabular}

Abbreviations available in table 1 and table 3, except for Univ = University.

Another interesting view on influence of the authors publishing on Customer Relationship Management research is the study of the co-citations between them. Considering them and using a graphic interface (Vos Viewer), we can see in Fig 3 the connections between authors that have cited each other studies about this subject.
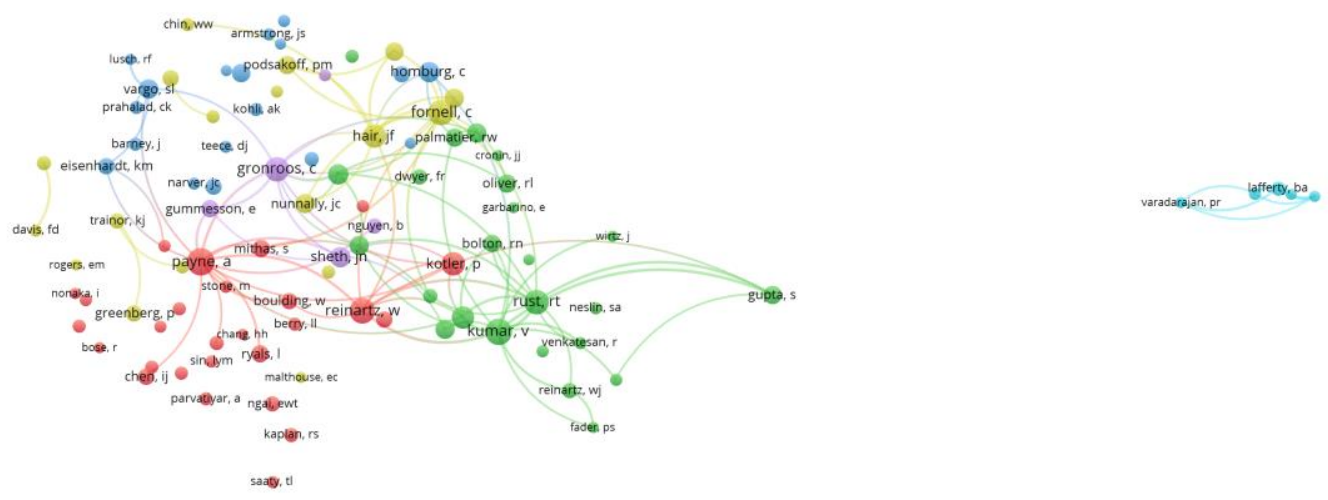

As vosviewer

Fig 3. Author co-citations with threshold of 20 citations showing 100 most representative connections

Fig 3 shows an isolated group of co-cited authors where Lafferty is the most relevant one. The rest of the relationships show a very interactive picture where most of the authors have been co-cited by the others, with some special relevant ones: Payne, Reinartz, Gronroos, Hair, Fornell, Kotler, Kumar, Rust. This research has been made reducing the field of study to the 100 most representative connections and considering only the authors with at least 20 citations.

\section{The most productive and influential institutions}

The two institutions with highest number of published papers in CRM research are Ghent University (from Belgium) and Hong Kong Polytechnic University (from Peoples R China), with more than 30 papers in the subject. Not far from them, with more than 20 published papers there are Georgia State University (from USA) and University of North Carolina (also from USA).

Concerning the influence of each institution, University of Maryland College Park (from USA) is the one with highest number of total citations (2.070). Next one in the rank is University of Texas Austin (from 
USA), with 1.991 citations, near the 2.000. In the next group of influence there are 6 Universities with more than 1.000 citations: Cranfield University from England (UK), Ghent University from Belgium, Georgia State University from USA, University of Groningen from Netherlands, Erasmus University of Rotterdam from Netherlands, and University of Munster from Germany. In the first eight positions regarding number of citations, there are then three Universities from USA and two from Netherlands.

If we look into the number of citations per published paper, there are clearly three Universities in the highest positions of the rank: University of Texas Austin (USA), University of Maryland College Park (USA) and Eindhoven University of Technology (Netherlands).

Considering the global picture of all indicators, the most productive and influential entity is Ghent University from Belgium, with the highest number of published papers, the highest h-index, and the fourth position in the rank of total number of citations.

Institutions from all over the world have contributed to Customer Relationship Management research during all the time, but it is clear than a great majority of them are established in USA. There are 25 institutions from USA between the 50 world wide more productive and influential institutions in CRM research, exactly half of the total quantity of institutions contributing to the subject. Other relevant countries are Taiwan (5 institutions), South Korea (4 institutions), and with 3 institutions each one: Peoples R China, Netherlands, and England (UK).

Special case to consider is the Islamic Azad University from Iran, with 10 published papers, nearly to most Universities of the list, but with really small number of citations (only 25) very far from the rest of the institutions.

Table 5. The 50 most productive and influential institutions

\begin{tabular}{|c|c|c|c|c|c|c|c|c|c|c|c|}
\hline $\mathrm{R}$ & Ins titution & Country & $\mathrm{TP}$ & $\mathrm{TC}$ & $\mathrm{TC} / \mathrm{TP}$ & $\mathrm{h}$ & $\begin{array}{l}>= \\
100\end{array}$ & $\begin{array}{l}>= \\
50\end{array}$ & $\begin{array}{l}>= \\
20\end{array}$ & ARWU & QS \\
\hline 1 & $\begin{array}{l}\text { GHENT } \\
\text { UNIVERSITY }\end{array}$ & Belgium & 31 & 1.431 & 46,16 & 21 & 4 & 11 & 22 & 61 & 58.4 \\
\hline 2 & $\begin{array}{l}\text { HONG KONG } \\
\text { POLYTECHNIC } \\
\text { UNIVERSITY }\end{array}$ & $\begin{array}{l}\text { Peoples } \quad \mathrm{R} \\
\text { China }\end{array}$ & 30 & 948 & 31,60 & 15 & 1 & 4 & 12 & $\begin{array}{l}201- \\
300\end{array}$ & 106 \\
\hline 3 & $\begin{array}{l}\text { GEORGIA STATE } \\
\text { UNIVERSITY }\end{array}$ & USA & 25 & 1.366 & 54,64 & 16 & 4 & 7 & 15 & - & $\begin{array}{l}701- \\
750\end{array}$ \\
\hline 4 & $\begin{array}{l}\text { UNIVERSITY OF } \\
\text { NORTH } \\
\text { CAROLINA }\end{array}$ & USA & 22 & 686 & 31,18 & 13 & 0 & 5 & 12 & 30 & - \\
\hline 5 & $\begin{array}{l}\text { CRANFIELD } \\
\text { UNIVERSITY }\end{array}$ & England & 19 & 1.684 & 88,63 & 13 & 4 & 7 & 11 & - & 45 \\
\hline 6 & $\begin{array}{l}\text { NORTHWESTERN } \\
\text { UNIVERSITY }\end{array}$ & USA & 19 & 938 & 49,37 & 11 & 3 & 6 & 10 & 25 & 34 \\
\hline 7 & $\begin{array}{ll}\text { UNIVERSITY } & \text { OF } \\
\text { GRONINGEN } & \end{array}$ & Netherlands & 17 & 1.204 & 70,82 & 13 & 4 & 8 & 13 & 66 & 120 \\
\hline 8 & $\begin{array}{l}\text { UNIVERSITY OF } \\
\text { MARYLAND } \\
\text { COLLEGE PARK }\end{array}$ & USA & 17 & 2.070 & 121,76 & 14 & 7 & 10 & 14 & 51 & 126 \\
\hline 9 & $\begin{array}{l}\text { UNIVERSITY OF } \\
\text { CONNECTICUT }\end{array}$ & USA & 15 & 979 & 65,27 & 13 & 2 & 7 & 12 & $\begin{array}{l}301- \\
400\end{array}$ & 373 \\
\hline 10 & $\begin{array}{l}\text { UNIVERSITY OF } \\
\text { MUNSTER }\end{array}$ & Germany & 15 & 1.094 & 72,93 & 8 & 2 & 5 & 7 & - & - \\
\hline 11 & $\begin{array}{l}\text { TEXAS A } \quad \text { M } \\
\text { UNIVERSITY } \\
\text { COLLEGE } \\
\text { STATION }\end{array}$ & USA & 14 & 876 & 62,57 & 12 & 2 & 6 & 9 & - & - \\
\hline
\end{tabular}




\begin{tabular}{|c|c|c|c|c|c|c|c|c|c|c|c|}
\hline 12 & $\begin{array}{l}\text { UNIVERSITY OF } \\
\text { VIRGINIA }\end{array}$ & USA & 14 & 677 & 48,36 & 11 & 1 & 7 & 9 & $\begin{array}{l}151- \\
200\end{array}$ & 192 \\
\hline 13 & $\begin{array}{l}\text { ERASMUS } \\
\text { UNIVERSITY } \\
\text { ROTTERDAM }\end{array}$ & Netherlands & 13 & 1.121 & 86,23 & 11 & 2 & 7 & 11 & - & 179 \\
\hline 14 & $\begin{array}{l}\text { NATIONAL } \\
\text { CHENG KUNG } \\
\text { UNIVERSITY }\end{array}$ & Taiwan & 13 & 268 & 20,62 & 10 & 0 & 1 & 5 & $\begin{array}{l}301- \\
400\end{array}$ & 234 \\
\hline 15 & $\begin{array}{l}\text { UNIVERSITY OF } \\
\text { PENNSYLVANIA }\end{array}$ & USA & 13 & 558 & 42,92 & 12 & 0 & 6 & 10 & 16 & 19 \\
\hline 16 & $\begin{array}{l}\text { UNIVERSITY OF } \\
\text { WASHINGTON }\end{array}$ & USA & 13 & 760 & 58,46 & 9 & 4 & 6 & 7 & 14 & 66 \\
\hline 17 & $\begin{array}{l}\text { YONSEI } \\
\text { UNIVERSITY }\end{array}$ & South Korea & 13 & 301 & 23,15 & 9 & 0 & 2 & 5 & $\begin{array}{l}301- \\
400\end{array}$ & 107 \\
\hline 18 & $\begin{array}{l}\text { DARTMOUTH } \\
\text { COLLEGE }\end{array}$ & USA & 12 & 846 & 70,50 & 10 & 3 & 4 & 8 & $\begin{array}{l}201- \\
300\end{array}$ & 183 \\
\hline 19 & $\begin{array}{l}\text { KOREA } \\
\text { ADVANCED } \\
\text { INSTITUTE OF } \\
\text { SCIENCE } \\
\text { TECHNOLOGY } \\
\text { KAIST }\end{array}$ & South Korea & 12 & 442 & 36,83 & 11 & 0 & 4 & 9 & - & - \\
\hline 20 & $\begin{array}{l}\text { UNIVERSITY OF } \\
\text { TEXAS AUSTIN }\end{array}$ & USA & 12 & 1.991 & 165,92 & 11 & 4 & 8 & 11 & - & 63 \\
\hline 21 & $\begin{array}{l}\text { CHINESE } \\
\text { ACADEMY } \\
\text { SCIENCES }\end{array}$ & $\begin{array}{l}\text { Peoples } \mathrm{R} \\
\text { China }\end{array}$ & 11 & 167 & 15,18 & 6 & 0 & 1 & 4 & - & $\begin{array}{l}51- \\
100\end{array}$ \\
\hline 22 & $\begin{array}{l}\text { EWHA WOMANS } \\
\text { UNIVERSITY }\end{array}$ & South Korea & 11 & 217 & 19,73 & 6 & 0 & 2 & 3 & $\begin{array}{l}401- \\
500\end{array}$ & 319 \\
\hline 23 & $\begin{array}{l}\text { NATIONAL } \\
\text { CHENGCHI } \\
\text { UNIVERSITY }\end{array}$ & Taiwan & 11 & 91 & 8,27 & 7 & 0 & 0 & 0 & - & $\begin{array}{l}601- \\
650\end{array}$ \\
\hline 24 & $\begin{array}{l}\text { UNIVERSITY OF } \\
\text { PADUA }\end{array}$ & Italy & 11 & 233 & 21,18 & 7 & 0 & 1 & 5 & $\begin{array}{l}201- \\
300\end{array}$ & - \\
\hline 25 & $\begin{array}{l}\text { UNIVERSITY OF } \\
\text { WASHINGTON } \\
\text { SEATTLE }\end{array}$ & USA & 11 & 683 & 62,09 & 7 & 4 & 5 & 5 & - & - \\
\hline 26 & $\begin{array}{l}\text { CITY } \\
\text { UNIVERSITY OF } \\
\text { HONG KONG }\end{array}$ & $\begin{array}{l}\text { Peoples } \\
\text { China }\end{array}$ & 10 & 366 & 36,60 & 7 & 1 & 2 & 5 & $\begin{array}{l}201- \\
300\end{array}$ & 55 \\
\hline 27 & $\begin{array}{l}\text { DUKE } \\
\text { UNIVERSITY }\end{array}$ & USA & 10 & 948 & 94,80 & 9 & 4 & 5 & 9 & 26 & 26 \\
\hline 28 & $\begin{array}{l}\text { INTERNATIONAL } \\
\text { BUSINESS } \\
\text { MACHINES IBM }\end{array}$ & India & 10 & 400 & 40,00 & 6 & 0 & 5 & 6 & - & - \\
\hline 29 & $\begin{array}{l}\text { ISLAMIC AZAD } \\
\text { UNIVERSITY }\end{array}$ & Iran & 10 & 25 & 2,50 & 2 & 0 & 0 & 0 & - & - \\
\hline 30 & $\begin{array}{l}\text { LOUISIANA } \\
\text { STATE } \\
\text { UNIVERSITY }\end{array}$ & USA & 10 & 569 & 56,90 & 8 & 2 & 4 & 7 & $\begin{array}{l}301- \\
400\end{array}$ & $\begin{array}{l}651- \\
700\end{array}$ \\
\hline
\end{tabular}




\begin{tabular}{|c|c|c|c|c|c|c|c|c|c|c|c|}
\hline 31 & $\begin{array}{l}\text { NATIONAL } \\
\text { CHUNG CHENG } \\
\text { UNIVERSITY }\end{array}$ & Taiwan & 10 & 168 & 16,80 & 7 & 0 & 1 & 2 & - & $\begin{array}{l}801- \\
1000\end{array}$ \\
\hline 32 & $\begin{array}{l}\text { NATIONAL } \\
\text { TSING HUA } \\
\text { UNIVERSITY }\end{array}$ & Taiwan & 10 & 159 & 15,90 & 8 & 0 & 1 & 2 & $\begin{array}{l}401- \\
500\end{array}$ & 163 \\
\hline 33 & $\begin{array}{l}\text { PURDUE } \\
\text { UNIVERSITY }\end{array}$ & USA & 10 & 233 & 23,30 & 8 & 0 & 2 & 4 & $\begin{array}{l}301- \\
400\end{array}$ & 100 \\
\hline 34 & $\begin{array}{l}\text { TAMKANG } \\
\text { UNIVERSITY }\end{array}$ & Taiwan & 10 & 109 & 10,90 & 5 & 0 & 0 & 2 & - & - \\
\hline 35 & $\begin{array}{l}\text { UNIVERSITY OF } \\
\text { GEORGIA }\end{array}$ & USA & 10 & 489 & 48,90 & 8 & 1 & 3 & 5 & $\begin{array}{l}201- \\
300\end{array}$ & 431 \\
\hline 36 & $\begin{array}{l}\text { UNIVERSITY OF } \\
\text { HOUSTON }\end{array}$ & USA & 10 & 472 & 47,20 & 7 & 2 & 5 & 6 & $\begin{array}{l}201- \\
301\end{array}$ & $\begin{array}{l}651- \\
700\end{array}$ \\
\hline 37 & $\begin{array}{l}\text { UNIVERSITY OF } \\
\text { SOUTH } \\
\text { CAROLINA }\end{array}$ & USA & 10 & 571 & 57,10 & 8 & 1 & 3 & 6 & - & $\begin{array}{l}561- \\
570\end{array}$ \\
\hline 38 & $\begin{array}{l}\text { EMORY } \\
\text { UNIVERSITY }\end{array}$ & USA & 9 & 634 & 70,44 & 7 & 1 & 3 & 5 & $\begin{array}{l}101- \\
150\end{array}$ & 148 \\
\hline 39 & $\begin{array}{l}\text { INDIANA } \\
\text { UNIVERSITY } \\
\text { BLOOMINGTON }\end{array}$ & USA & 9 & 387 & 43,00 & 7 & 0 & 3 & 6 & $\begin{array}{l}101- \\
150\end{array}$ & 323 \\
\hline 40 & $\begin{array}{l}\text { NATIONAL } \\
\text { UNIVERSITY OF } \\
\text { SINGAPORE }\end{array}$ & Singapore & 9 & 280 & 31,11 & 6 & 0 & 3 & 4 & 85 & 11 \\
\hline 41 & $\begin{array}{l}\text { SEOUL } \\
\text { NATIONAL } \\
\text { UNIVERSITY }\end{array}$ & South Korea & 9 & 146 & 16,22 & 5 & 0 & 1 & 1 & $\begin{array}{l}101- \\
150\end{array}$ & 36 \\
\hline 42 & $\begin{array}{l}\text { TEMPLE } \\
\text { UNIVERSITY }\end{array}$ & USA & 9 & 150 & 16,67 & 6 & 0 & 1 & 3 & $\begin{array}{l}301- \\
400\end{array}$ & $\begin{array}{l}651- \\
700\end{array}$ \\
\hline 43 & $\begin{array}{l}\text { UNIVERSITY OF } \\
\text { LONDON }\end{array}$ & England & 9 & 322 & 35,78 & 6 & 0 & 2 & 6 & $\begin{array}{l}151- \\
200\end{array}$ & 351 \\
\hline 44 & $\begin{array}{l}\text { UNIVERSITY OF } \\
\text { MANCHESTER }\end{array}$ & England & 9 & 301 & 33,44 & 6 & 1 & 2 & 5 & 34 & 29 \\
\hline 45 & $\begin{array}{ll}\text { UNIVERSITY } & \text { OF } \\
\text { MISSOURI } & \\
\text { COLUMBIA } & \end{array}$ & USA & 9 & 430 & 47,78 & 6 & 2 & 4 & 5 & - & $\begin{array}{l}591- \\
600\end{array}$ \\
\hline 46 & $\begin{array}{l}\text { UNIVERSITY OF } \\
\text { NORTH } \\
\text { CAROLINA } \\
\text { CHAPEL HILL }\end{array}$ & USA & 9 & 290 & 32,22 & 8 & 0 & 2 & 6 & - & 83 \\
\hline 47 & $\begin{array}{l}\text { UNIVERSITY OF } \\
\text { TEHRAN }\end{array}$ & Iran & 9 & 92 & 10,22 & 3 & 0 & 0 & 2 & $\begin{array}{l}301- \\
400\end{array}$ & $\begin{array}{l}701- \\
750\end{array}$ \\
\hline 48 & $\begin{array}{l}\text { UNIVERSITY OF } \\
\text { TEXAS AT SAN } \\
\text { ANTONIO UTSA }\end{array}$ & USA & 9 & 89 & 9,89 & 4 & 0 & 0 & 2 & - & - \\
\hline 49 & $\begin{array}{l}\text { COLUMBIA } \\
\text { UNIVERSITY }\end{array}$ & USA & 8 & 551 & 68,88 & 7 & 3 & 5 & 5 & 8 & 16 \\
\hline 50 & $\begin{array}{l}\text { EINDHOVEN } \\
\text { UNIVERSITY OF } \\
\text { TECHNOLOGY }\end{array}$ & Netherlands & 8 & 967 & 120,88 & 7 & 1 & 4 & 7 & $\begin{array}{l}301- \\
400\end{array}$ & 99 \\
\hline
\end{tabular}


Abbreviations available from table 1 and table 3; ARWU and QS = Ranking in the general ARWU and QS university rankings

\section{Country analysis}

Its very interesting to create a worldwide picture of the country origin of the publications. Country relates in this case to the institution that publishes the paper, but it does not consider the nationality of the researchers who wrote the pushed paper. This makes a tricky situation because lot of researches are used to moving into other countries as USA and UK.

Table 6 shows that USA is clearly the more productive Country with 561 published papers, very far from the 183 papers published by the second one in this case UK. Third Country in this rank is Taiwan, followed by Peoples R China and Germany.

Regarding total number of citations, again USA is clearly the most influential Country in Customer Management Relationship research with 21.966 citations currently. Very far from USA, UK counts with 4.737 citations, being the second more influential Country. Third there is Germany with 3.359 citations, and fourth in the rank there is Netherlands with 3.304 citations so far.

354 Special mention deserves Spain, where we are developing this research from Universitat Politècnica de València. Spain appears in a commendable eight position of the total of published papers rank.

Finally, in order to take a relative picture of the most productive and influential countries, it's worth to consider the population of each Country and to consider the ratios between total number of papers and total number of citations modelled by the Country population. With this ratio in consideration, Taiwan appears the first as the most productive country on Customer Relationship Management research, with 6,92 papers per million of population. Next to Taiwan there are Cyprus (5,93 papers per million of population) and Finland (with 5,81 papers per million of population). This ratio moves down some of the most productive Countries due to their high Population, for example USA now appears in the seventeenth position, UK in the ninth position, and Peoples R China in the forty fourth position at the bottom of the list.

Same occurs if we divide the total number of cites by the population of the Country. In this case Netherlands comes to the first position in the rank, followed by Belgium, New Zealand, Singapore, and Taiwan. USA and UK which were considered the most absolute influential Countries regarding total number of citations, now appear in eighth and seventh position respectively.

368

Table 6. The most productive and influential Countries in CRM research

\begin{tabular}{|c|c|c|c|c|c|c|c|c|c|c|c|}
\hline $\mathrm{R}$ & Country & TP & $\mathrm{TC}$ & $\begin{array}{l}\mathrm{TC} / \mathrm{T} \\
\mathrm{P}\end{array}$ & $\mathrm{h}$ & Pop & $\begin{array}{l}\mathrm{TP} / \mathrm{P} \\
\text { op }\end{array}$ & $\begin{array}{l}\mathrm{TC} / \mathrm{P} \\
\mathrm{op}\end{array}$ & $\begin{array}{l}>= \\
100\end{array}$ & $\begin{array}{l}>= \\
50\end{array}$ & $\begin{array}{l}>= \\
20\end{array}$ \\
\hline 1 & USA & 561 & $\begin{array}{l}21.96 \\
6\end{array}$ & $\begin{array}{l}39,1 \\
6\end{array}$ & 77 & $325.719,18$ & 1,72 & 67,44 & 57 & 130 & 252 \\
\hline 2 & UK & 183 & 4.737 & $\begin{array}{l}25,8 \\
9\end{array}$ & 35 & $66.022,27$ & 2,77 & 71,75 & 7 & 24 & 57 \\
\hline 3 & TAIWAN & 163 & 2.476 & $\begin{array}{l}15,1 \\
9\end{array}$ & 27 & $23.545,96$ & 6,92 & $\begin{array}{l}105,1 \\
6\end{array}$ & 1 & 11 & 39 \\
\hline 4 & $\begin{array}{l}\text { PEOPLES } \\
\text { R CHINA }\end{array}$ & 130 & 2.731 & $\begin{array}{l}21,0 \\
1\end{array}$ & 30 & $\begin{array}{l}1.386 .395 \\
00\end{array}$ & 0,09 & 1,97 & 4 & 11 & 42 \\
\hline 5 & $\begin{array}{l}\text { GERMAN } \\
\mathrm{Y}\end{array}$ & 110 & 3.359 & $\begin{array}{l}30,5 \\
4\end{array}$ & 26 & $82.695,00$ & 1,33 & 40,62 & 6 & 15 & 32 \\
\hline 6 & $\begin{array}{l}\text { SOUTH } \\
\text { KOREA }\end{array}$ & 85 & 2.021 & $\begin{array}{l}23,7 \\
8\end{array}$ & 24 & $51.466,20$ & 1,65 & 39,27 & 3 & 13 & 29 \\
\hline 7 & $\begin{array}{l}\text { AUSTRAL } \\
\text { IA }\end{array}$ & 69 & 1.307 & $\begin{array}{l}18,9 \\
4\end{array}$ & 21 & $24.598,93$ & 2,81 & 53,13 & 2 & 5 & 22 \\
\hline 8 & SPAIN & 60 & 858 & $\begin{array}{l}14,3 \\
0\end{array}$ & 16 & $46.572,03$ & 1,29 & 18,42 & 1 & 6 & 14 \\
\hline
\end{tabular}




\begin{tabular}{|c|c|c|c|c|c|c|c|c|c|c|c|}
\hline 9 & ITALY & 57 & 611 & $\begin{array}{l}10,7 \\
2\end{array}$ & 15 & $60.551,42$ & 0,94 & 10,09 & 0 & 3 & 13 \\
\hline 10 & INDIA & 56 & 428 & 7,64 & 10 & $\begin{array}{l}1.339 .180 \\
13\end{array}$ & 0,04 & 0,32 & 0 & 4 & 6 \\
\hline 11 & FRANCE & 54 & 1.538 & $\begin{array}{l}28,4 \\
8\end{array}$ & 16 & $67.118,65$ & 0,80 & 22,91 & 4 & 6 & 14 \\
\hline 12 & $\begin{array}{l}\text { NETHERL } \\
\text { ANDS }\end{array}$ & 52 & 3.304 & $\begin{array}{l}63,5 \\
4\end{array}$ & 28 & $17.132,85$ & 3,04 & $\begin{array}{l}192,8 \\
5\end{array}$ & 7 & 18 & 34 \\
\hline 13 & CANADA & 51 & 1.941 & $\begin{array}{l}38,0 \\
6\end{array}$ & 19 & $36.708,08$ & 1,39 & 52,88 & 6 & 13 & 19 \\
\hline 14 & BELGIUM & 43 & 1.685 & $\begin{array}{l}39,1 \\
9\end{array}$ & 24 & $11.372,07$ & 3,78 & $\begin{array}{l}148,1 \\
7\end{array}$ & 4 & 14 & 26 \\
\hline 15 & IRAN & 37 & 258 & 6,97 & 8 & $81.162,79$ & 0,46 & 3,18 & 0 & 0 & 4 \\
\hline 16 & FINLAND & 32 & 434 & $\begin{array}{l}13,5 \\
6\end{array}$ & 11 & $5.511,30$ & 5,81 & 78,75 & 0 & 3 & 7 \\
\hline 17 & TURKEY & 30 & 262 & 8,73 & 9 & $80.745,02$ & 0,37 & 3,24 & 0 & 0 & 6 \\
\hline 18 & GREECE & 22 & 317 & $\begin{array}{l}14,4 \\
1\end{array}$ & 8 & $10.760,42$ & 2,04 & 29,46 & 0 & 2 & 6 \\
\hline 19 & $\begin{array}{l}\text { SWITZER } \\
\text { LAND }\end{array}$ & 22 & 142 & 6,45 & 5 & $8.466,02$ & 2,60 & 16,77 & 0 & 1 & 2 \\
\hline 20 & $\begin{array}{l}\text { SINGAPO } \\
\text { RE }\end{array}$ & 20 & 653 & $\begin{array}{l}32,6 \\
5\end{array}$ & 10 & $5.612,25$ & 3,56 & $\begin{array}{l}116,3 \\
5\end{array}$ & 2 & 5 & 8 \\
\hline 21 & SWEDEN & 19 & 172 & 9,05 & 7 & $10.067,74$ & 1,89 & 17,08 & 0 & 1 & 3 \\
\hline 22 & BRAZIL & 16 & 220 & $\begin{array}{l}13,7 \\
5\end{array}$ & 5 & $209.288,28$ & 0,08 & 1,05 & 1 & 1 & 3 \\
\hline 23 & $\begin{array}{l}\text { PORTUGA } \\
\text { L }\end{array}$ & 16 & 337 & $\begin{array}{l}21,0 \\
6\end{array}$ & 6 & $10.293,72$ & 1,55 & 32,74 & 1 & 2 & 4 \\
\hline 24 & NORWAY & 14 & 162 & $\begin{array}{l}11,5 \\
7\end{array}$ & 8 & $5.282,22$ & 2,65 & 30,67 & 0 & 0 & 3 \\
\hline 25 & $\begin{array}{l}\text { DENMAR } \\
\mathrm{K}\end{array}$ & 13 & 148 & $\begin{array}{l}11,3 \\
8\end{array}$ & 7 & $5.769,60$ & 2,25 & 25,65 & 0 & 0 & 2 \\
\hline 26 & $\begin{array}{l}\text { MALAYSI } \\
\text { A }\end{array}$ & 13 & 65 & 5,00 & 5 & $31.624,26$ & 0,41 & 2,06 & 0 & 0 & 1 \\
\hline 27 & JAPAN & 12 & 210 & $\begin{array}{l}17,5 \\
0\end{array}$ & 6 & $126.785,80$ & 0,09 & 1,66 & 0 & 1 & 4 \\
\hline 28 & POLAND & 12 & 60 & 5,00 & 4 & $37.975,84$ & 0,32 & 1,58 & 0 & 0 & 1 \\
\hline 29 & AUSTRIA & 11 & 303 & $\begin{array}{l}27,5 \\
5\end{array}$ & 5 & $8.809,21$ & 1,25 & 34,40 & 1 & 2 & 4 \\
\hline 30 & $\begin{array}{l}\text { NEW } \\
\text { ZEALAND }\end{array}$ & 11 & 630 & $\begin{array}{l}57,2 \\
7\end{array}$ & 6 & $4.793,90$ & 2,29 & $\begin{array}{l}131,4 \\
2\end{array}$ & 1 & 1 & 4 \\
\hline 31 & $\begin{array}{l}\text { SOUTH } \\
\text { AFRICA }\end{array}$ & 11 & 88 & 8,00 & 3 & $56.717,16$ & 0,19 & 1,55 & 0 & 1 & 1 \\
\hline 32 & ISRAEL & 9 & 204 & $\begin{array}{l}22,6 \\
7\end{array}$ & 6 & $8.712,40$ & 1,03 & 23,41 & 0 & 2 & 4 \\
\hline 33 & $\begin{array}{l}\text { ROMANI } \\
\text { A }\end{array}$ & 8 & 13 & 1,63 & 2 & $19.586,54$ & 0,41 & 0,66 & 0 & 0 & 0 \\
\hline 34 & $\begin{array}{l}\text { SLOVENI } \\
\text { A }\end{array}$ & 8 & 81 & $\begin{array}{l}10,1 \\
3\end{array}$ & 4 & $2.066,75$ & 3,87 & 39,19 & 0 & 0 & 2 \\
\hline 35 & UKRAINE & 8 & 4 & 0,50 & 1 & $44.831,16$ & 0,18 & 0,09 & 0 & 0 & 0 \\
\hline
\end{tabular}




\begin{tabular}{|c|c|c|c|c|c|c|c|c|c|c|c|}
\hline 36 & CYPRUS & 7 & 15 & 2,14 & 2 & $1.179,55$ & 5,93 & 12,72 & 0 & 0 & 0 \\
\hline 37 & IRELAND & 7 & 63 & 9,00 & 4 & $4.813,61$ & 1,45 & 13,09 & 0 & 0 & 1 \\
\hline 38 & $\begin{array}{l}\text { LITHUAN } \\
\text { IA }\end{array}$ & 7 & 58 & 8,29 & 4 & $2.827,72$ & 2,48 & 20,51 & 0 & 0 & 0 \\
\hline 39 & $\begin{array}{l}\text { SAUDI } \\
\text { ARABIA }\end{array}$ & 7 & 11 & 1,57 & 1 & $32.938,21$ & 0,21 & 0,33 & 0 & 0 & 0 \\
\hline 40 & $\begin{array}{l}\text { SLOVAKI } \\
\text { A }\end{array}$ & 7 & 18 & 2,57 & 3 & $5.439,89$ & 1,29 & 3,31 & 0 & 0 & 0 \\
\hline 41 & CROATIA & 6 & 73 & $\begin{array}{l}12,1 \\
7\end{array}$ & 3 & $4.125,70$ & 1,45 & 17,69 & 0 & 1 & 1 \\
\hline 42 & $\begin{array}{l}\text { PAKISTA } \\
\mathrm{N}\end{array}$ & 6 & 17 & 2,83 & 2 & $197.015,95$ & 0,03 & 0,09 & 0 & 0 & 0 \\
\hline 43 & RUSSIA & 6 & 4 & 0,67 & 1 & $144.495,04$ & 0,04 & 0,03 & 0 & 0 & 0 \\
\hline 44 & $\begin{array}{l}\text { THAILAN } \\
\text { D }\end{array}$ & 6 & 31 & 5,17 & 2 & $69.037,51$ & 0,09 & 0,45 & 0 & 0 & 0 \\
\hline 45 & $\begin{array}{l}\text { BOSNIA } \\
\text { HERCEG }\end{array}$ & 5 & 3 & 0,60 & 1 & $3.507,02$ & 1,43 & 0,86 & 0 & 0 & 0 \\
\hline 46 & PERU & 5 & 66 & $\begin{array}{l}13,2 \\
0\end{array}$ & 3 & $32.165,49$ & 0,16 & 2,05 & 0 & 0 & 2 \\
\hline 47 & $\begin{array}{l}\text { BANGLA } \\
\text { DESH }\end{array}$ & 4 & 22 & 5,50 & 1 & $164.669,75$ & 0,02 & 0,13 & 0 & 0 & 1 \\
\hline 48 & CHILE & 4 & 45 & $\begin{array}{l}11,2 \\
5\end{array}$ & 3 & $18.054,73$ & 0,22 & 2,49 & 0 & 0 & 1 \\
\hline 49 & $\begin{array}{l}\text { CZECH } \\
\text { REPUBLI } \\
\text { C }\end{array}$ & 4 & 11 & 2,75 & 2 & $10.591,32$ & 0,38 & 1,04 & 0 & 0 & 0 \\
\hline 50 & $\begin{array}{l}\text { HUNGAR } \\
\mathrm{Y}\end{array}$ & 4 & 10 & 2,50 & 1 & $9.781,13$ & 0,41 & 1,02 & 0 & 0 & 0 \\
\hline
\end{tabular}

Abbreviations from table 1 and table 3, except for Pop = Population (thousands); TP/Pop = Studies per millions of Population; TC/Pop $=$ Citations per millions of Population

\section{Conclusion}

This paper has presented a global overview of the Customer Relationship Management during all its lifecycle up-to-nowadays, with clear conclusions about the takeoff of this technology since year 2.000, and with increasingly influence in the market and the scientific research. The picture obtained about Customer Management Relationship (CRM) has been developed by using bibliometric indicators. The results were generated by using Web of Science (WoS), a general scientific database widely considered currently as one of the most influential one for scientific research. The main contribution of this paper is to use the modern bibliometric tools in order to show how the influence of CRM has been increasing during last decades, being this study supported by the different modern indicators that are being usually considered in the literature. This stated growing influence of CRM during last decades, is the pillar for future invests on investigation about how market is perceiving the value of CRM and which benefits is this technology bringing to modern, dynamic, and successful firms nowadays. Besides, the identified as the most influential authors, institutions, and countries, may be the main study sphere for new and future researches in this field.

After the study, we can conclude that the most influential Journals or Source Titles in the CRM field are clearly EXPERT SYSTEMS WITH APPLICATIONS and JOURNAL OF MARKETING, assessed by the different variables considered in this study, mainly considering the h-index and number of papers with more than 100 citations. The second group of influence is composed by INDUSTRIAL MARKETING MANAGEMENT, JOURNAL OF THE ACADEMY OF MARKETING SCIENCE, DECISION SUPPORT 
SYSTEMS, and JOURNAL OF BUSINESS RESEARCH, again considering the h-index and the total number of papers published by them and their citations. A challenge of this study is the low number of journals publishing about CRM all over the time; this issue permits, on other hand, a most selective research, focusing in the highest quality ones.

Concerning the qualitative evolution of the subject in the publishing and citing registries, it shows a clear point of inflection in year 2.000, where both number of papers published, and number of citations, started the take-off with a lineal progression. Only since year 2011 to year 2014 the number of publications were lightly going down, but quickly recovering the increasing tendency in 2015.

Clear enough seems the number of citations to conclude about the youngness of the technology. Only 20 percent of the all-time papers have been cited more than 50 times, showing the long path that technology has still to walk in order to arrive to a mature point where the volume of researches and publications may convert it into a study hit.

USA and UK are clearly the most productive and influential Countries concerning most of the analyzed parameters. The most productive authors (with the highest number of publications) come from USA, followed by US and Taiwan. In the same line, institutions from all over the world have contributed to Customer Relationship Management research during all the time, but it is clear than a great majority of them are established in USA: 25 institutions from USA are between the 50 world wide more productive and influential institutions in CRM research, exactly half of the total quantity of institutions contributing to the subject, followed by Taiwan, South Korea, Peoples R China, Netherlands, and England (UK). Finally, if we consider the Countries themselves, the absolute indicators show again the prominent position of USA as the Country with the highest number of papers and citations, far from the second one UK. Other countries like Taiwan, Peoples R China, and Germany stand out about papers published, and other ones as Netherlands, Taiwan, Peoples R China, South Korea, Canada, and Belgium stand out about number of citations.

The main findings of this paper are useful for obtaining a global overview of the state of the art in Customer Relationship Management research according to bibliometric information. The main indicators studied and analyzed have been the number of papers published, the total amount of citations, the h-index, and the most cited items in each category, all of them key indicators for bibliometric analysis. There is a first limitation on this study, considering that this paper aims to be informative in order to identify some relevant research, but also stating that this study is based in the Web Of Science (WoS) so other influential research that is not collected in the WoS is not included in this study. The second limitation is that the ranks used to present the information, in order to classify and analyze the information, are purely informative and not an official result, based on the bibliometric data found in the WoS. Therefore, this paper only provides general information for the general understanding of the field of CRM, but many other issues could be considered in order to getting a complete picture of the state of the art.

The future research efforts may have to be with identifying the most important benefits that the three CRM modules (Sales, Marketing, and Services) can provide the companies with after deploying and effectively using this technology. This would be the base for setting the keyclues for showing the critical success factors for companies directly related to the use of CRM solutions.

It is thus determined as a general conclusion that the growing interest in the study of CRM is the demonstration of how the search for sustainable business management models can be based on the intensive and efficient use of CRM as a key technological solution for effective and successful business management. Having determined which authors, entities, and countries are most influential in this field of study, as well as having identified the most influential papers, will be the basis for initiating the next research initiatives in this field.

\section{References}

Allen, L., Jones, C., Dolby, K., Lynn, D., \& Walport, M. (2009). Looking for landmarks: the role of expert review and bibliometric analysis in evaluating scientific publication outputs. PloS one, 4(6), e5910.

Attaran, M., Attaran, S., \& Kirkland, D. (2019). The Need for Digital Workplace: Increasing Workforce Productivity in the Information Age. International Journal of Enterprise Information Systems (IJEIS), 15(1), 1-23. 
Autor, D. (2012). The Journal of Economic Perspectives at 100 (Issues). Journal of Economic Perspectives, 26(2), 3-18.

Bar-Ilan, J. (2008). Informetrics at the beginning of the 21 st century-A review. Journal of informetrics, 2(1), 1-52.

Baumgartner, H., \& Pieters, R. (2003). The structural influence of marketing journals: A citation analysis of the discipline and its subareas over time. Journal of marketing, 67(2), 123-139.

Borokhovich, K. A., Bricker, R. J., Brunarski, K. R., \& Simkins, B. J. (1995). Finance research productivity and influence. The journal of finance, 50(5), 1691-1717.

Broadus, R. Toward a definition of "bibliometrics" Scientometrics. 1987; 12 (5-6): 373-379. doi: 10.1007. BF02016680.

Buttle F. (2004). Customer Relationship Management. Concepts and Tools. Oxford, UK: Elsevier, Butterworth-Heinemann.

Cadez, S. (2013). Social change, institutional pressures and knowledge creation: A bibliometric analysis. Expert systems with applications, 40(17), 6885-6893.

Card, D., \& DellaVigna, S. (2013). Nine facts about top journals in economics. Journal of Economic Literature, 51(1), 144-61.

Chan, K. C., Lai, P., \& Liano, K. (2012). A threshold citation analysis in marketing research. European Journal of Marketing, 46(1/2), 134-156.

Chan, K. C., Seow, G. S., \& Tam, K. (2009). Ranking accounting journals using dissertation citation analysis: A research note. Accounting, Organizations and Society, 34(6-7), 875-885.

Chan, K. C., Tong, J. Y., \& Zhang, F. F. (2012). Accounting journal rankings, authorship patterns and the author affiliation index. Australian Accounting Review, 22(4), 407-417.

Chao, C., Jen, W., Chi, Y., \& Lin, B. (2007). Determining technology trends and forecasts of CRM through a historical review and bibliometric analysis of data from 1991 to 2005. International Journal of Management and Enterprise Development, 4(4), 415-427.

Chen, I. J., \& Popovich, K. (2003). Understanding customer relationship management (CRM) People, process and technology. Business process management journal, 9(5), 672-688.

Deng, G. F., \& Lin, W. T. (2012). Citation analysis and bibliometric approach for ant colony optimization from 1996 to 2010. Expert Systems with Applications, 39(6), 6229-6237.

Dumas, M., La Rosa, M., Mendling, J., \& Reijers, H. A. (2018). Process-Aware Information Systems. In Fundamentals of Business Process Management (pp. 341-369). Springer, Berlin, Heidelberg.

Gil Gómez, H., Arango Serna, M. D., \& Oltra Badenes, R. F. (2010). Evolution and trends of information systems for business management: the M-Business. A Review. Dyna, 77(163), 181-193.Gomez-Mejia, L. R., \& Balkin, D. B. (1992). Determinants of faculty pay: An agency theory perspective. Academy of Management journal, 35(5), 921-955.

Grönroos, C. (1997). Value-driven relational marketing: from products to resources and competencies. Journal of marketing management, 13(5), 407-419.

Guerola-Navarro, V., Oltra-Badenes, R. y Gil-Gomez, H. (2020). Análisis de la relación entre el grado de introducción de CRM y los beneficios de la empresa a través del Desempeño Organizacional y la Innovación Empresarial. 3C Empresa. Investigación y pensamiento crítico, 9(1), 65-63. doi: http://dx.doi. org/10.17993/3cemp.2018.070436.65-85

Hirsch, J. E. (2005). An index to quantify an individual's scientific research output. Proceedings of the National academy of Sciences, 102(46), 16569-16572.

James, T. L., Cook, D. F., Conlon, S., Keeling, K. B., Collignon, S., \& White, T. (2015). A framework to explore innovation at SAP through bibliometric analysis of patent applications. Expert Systems with Applications, 42(24), 9389-9401.

King, S. F., \& Burgess, T. F. (2008). Understanding success and failure in customer relationship management. Industrial Marketing Management, 37(4), 421-431.

Kirkpatrick, S. A., \& Locke, E. A. (1992). The development of measures of faculty scholarship. Group \& Organization Management, 17(1), 5-23. 
Kocher, M. G., \& Sutter, M. (2001). The institutional concentration of authors in top journals of economics during the last two decades. The Economic Journal, 111(472), 405-421.

Laband, D. N. (2013). On the use and abuse of economics journal rankings. The Economic Journal, 123(570), F223-F254.

Laband, D. N., \& Piette, M. J. (1994). The relative impacts of economics journals: 1970-1990. Journal of economic Literature, 32(2), 640-666.

Liang, T. P., \& Liu, Y. H. (2018). Research landscape of business intelligence and big data analytics: A bibliometrics study. Expert Systems with Applications, 111, 2-10.

Merigó, J. M., Gil-Lafuente, A. M., \& Yager, R. R. (2015). An overview of fuzzy research with bibliometric indicators. Applied Soft Computing, 27, 420-433.

Negash, S., \& Gray, P. (2008). Business intelligence. In Handbook on decision support systems 2 (pp. 175-193). Springer, Berlin, Heidelberg.

Podsakoff, P. M., MacKenzie, S. B., Podsakoff, N. P., \& Bachrach, D. G. (2008). Scholarly influence in the field of management: A bibliometric analysis of the determinants of university and author impact in the management literature in the past quarter century. Journal of Management, 34(4), 641-720.

Stern, D. I. (2013). Uncertainty measures for economics journal impact factors. Journal of Economic Literature, 51(1), 173-89.

Sternberg, R., \& Litzenberger, T. (2005). The publication and citation output of German Faculties of Economics and Social Sciences-a comparison of faculties and disciplines based upon SSCI data. Scientometrics, 65(1), 29-53.

Stremersch, S., \& Verhoef, P. C. (2005). Globalization of authorship in the marketing discipline: does it help or hinder the field?. Marketing Science, 24(4), 585-594.

Süssmuth, B., Steininger, M., \& Ghio, S. (2006). Towards a European economics of economics: Monitoring a decade of top research and providing some explanation. Scientometrics, 66(3), 579-612.

Tellis, G. J., Chandy, R. K., \& Ackerman, D. S. (1999). In search of diversity: The record of major marketing journals. Journal of Marketing Research, 36(1), 120-131.

Trieschmann, J. S., Dennis, A. R., Northcraft, G. B., \& Nieme Jr, A. W. (2000). Serving constituencies in business schools: MBA program versus research performance. Academy of Management Journal, 43(6), 1130-1141.

Tsai, H. H. (2011). Research trends analysis by comparing data mining and customer relationship management through bibliometric methodology. Scientometrics, 87(3), 425-450.

Vicedo, P., Gil, H., Oltra-Badenes, R., \& Merigó, J. M. (2018, January). Critical Success Factors on ERP Implementations: A Bibliometric Analysis. In International Conference on Modelling and Simulation in Management Sciences (pp. 169-181). Springer, Cham.

Yin, M. S. (2013). Fifteen years of grey system theory research: A historical review and bibliometric analysis. Expert systems with Applications, 40(7), 2767-2775.

Zyoud, S. H., \& Fuchs-Hanusch, D. (2017). A bibliometric-based survey on AHP and TOPSIS techniques. Expert Systems 